\title{
Adaptation responses in milk fat yield and methane emissions of dairy cows when wheat was included in their diet for 16 weeks
}

\author{
P. J. Moate, ${ }^{* 1}$ J. L. Jacobs, ${ }^{*}$ M. C. Hannah, ${ }^{*}$ G. L. Morris, ${ }^{*}$ K. A. Beauchemin, $†$ P. S. Alvarez Hess, $\ddagger$ \\ R. J. Eckard,‡ Z. Liu,§ S. Rochfort,§\# W. J. Wales, ${ }^{*}$ and S. R. O. Williams* \\ ${ }^{*}$ Department of Economic Development, Jobs, Transport and Resources, Agriculture Research Victoria, Ellinbank, Victoria 3821, Australia \\ †Agriculture and Agri-Food Canada, Lethbridge, Alberta, Canada T1J 4B1 \\ $\ddagger$ Faculty of Veterinary and Agricultural Science, The University of Melbourne, Parkville, Victoria 3052, Australia \\ §Department of Economic Development, Jobs, Transport and Resources, Agriculture Research Victoria, 5 Ring Road, Bundoora, Victoria 3083, \\ Australia \\ \#School of Applied Systems Biology, La Trobe University, Bundoora, Victoria 3083, Australia
}

\begin{abstract}
Short-term studies have shown that feeding dairy cows diets containing a high proportion $(>40 \%)$ of wheat may result in reduced milk fat concentration and reduced $\mathrm{CH}_{4}$ emissions ( $\mathrm{g}$ of $\mathrm{CH}_{4} /$ cow per $\mathrm{d}$ ), but no long-term studies have been done on these responses. This study compared the milk production and $\mathrm{CH}_{4}$ responses when 24 dairy cows were fed diets containing high proportions of either wheat or corn over 16 wk. Cows were assigned to 2 groups and offered a diet (CRN) containing $10.0 \mathrm{~kg}$ of dry matter/d of crushed corn grain, $1.8 \mathrm{~kg}$ of dry matter/d of canola meal, 0.2 $\mathrm{kg}$ of dry matter/d of minerals, and $11.0 \mathrm{~kg}$ of dry matter/d of chopped alfalfa hay or a similar diet (WHT) in which wheat replaced the corn. Dry matter intake and milk yields of individual cows were measured daily. Methane emissions from individual cows were measured using controlled climate respiration chambers over 2 consecutive days during each of wk 4,10 , and 16. Milk composition was measured on the $2 \mathrm{~d}$ when cows were in chambers during wk 4,10, and 16 . Over the 16 -wk experimental period, total dry matter intake remained relatively constant and similar for the 2 dietary treatment groups. At wk 4, $\mathrm{CH}_{4}$ emission, $\mathrm{CH}_{4}$ yield (g of $\mathrm{CH}_{4} / \mathrm{kg}$ of dry matter intake), milk fat yield, and milk fat concentration were substantially less in cows fed the WHT diet compared with the same metrics in cows fed the CRN diet; but these differences were not apparent at wk 10 and 16. The responses over time in these metrics were not similar in all cows. In 4 cows fed the WHT diet, $\mathrm{CH}_{4}$ yield, milk fat concentration, and milk fat yield remained relatively constant from wk 4 to 16 , whereas for 5 fed the WHT diet, their $\mathrm{CH}_{4}$ emissions,
\end{abstract}

Received December 21, 2017.

Accepted March 21, 2018.

${ }^{1}$ Corresponding author: peter.moate@ecodev.vic.gov.au milk fat yields, and milk fat concentrations almost doubled between wk 4 and 16 . In the short term (4 wk), the inclusion of approximately $45 \%$ wheat instead of corn in the diet of cows resulted in reductions of $39 \%$ in $\mathrm{CH}_{4}$ yield, $35 \%$ in milk fat concentration, and $40 \%$ in milk fat yield. However, these reductions did not persist to wk 10 or beyond. Our data indicate that cows do not all respond in the same way with some "adaptive" cows showing a marked increase in $\mathrm{CH}_{4}$ yield, milk fat concentration, and milk fat yield after wk 4, whereas in other "nonadaptive" cows, these metrics were persistently inhibited to 16 wk. This research shows that short-term studies on dietary interventions to mitigate enteric $\mathrm{CH}_{4}$ emissions may not always predict the longterm effects of such interventions.

Key words: cattle, corn, adaptation, calorimeter

\section{INTRODUCTION}

Increasing the proportion of concentrate in the diet of ruminants has been shown to reduce $\mathrm{CH}_{4}$ yield ( $\mathrm{g} /$ $\mathrm{kg}$ of DMI; Sauvant et al., 2011), but the magnitude of the effect is not the same for all grains. Beef cattle fed corn had lower $\mathrm{CH}_{4}$ yields than cattle fed barley at the same proportion of the diet (Beauchemin and McGinn, 2005), and dairy cows fed wheat had lower $\mathrm{CH}_{4}$ yields and intensities $(\mathrm{g} / \mathrm{kg}$ of $\mathrm{ECM})$ than cows fed corn or barley (Moate et al., 2016, 2017). However, the mechanisms responsible for these reductions are not clear and whether or not these effects persist in the long term has not been reported in the scientific literature.

Dietary and other interventions have been shown to have marked effects on ruminal microorganisms involved in methanogenesis (Torok et al., 2014), and in some instances, the ruminal microbial population may take many weeks to adapt to an intervention (Weimer et al., 2010). Adaptation of rumen organisms is a phenomenon that may limit the usefulness of some specific 
dietary interventions for inhibiting $\mathrm{CH}_{4}$ emissions. For example, although some researchers have shown dietary supplementation with monensin reduced ruminant $\mathrm{CH}_{4}$ emissions in short-term experiments (Thornton and Owens, 1981), others have shown reductions in $\mathrm{CH}_{4}$ may not persist more than a few weeks (Sauer et al., 1998; Omar, 2004; Guan et al., 2006). Similarly, Klop et al. (2017) recently reported that the $\mathrm{CH}_{4}$ inhibitory effect of essential oils in dairy rations was transitory. In contrast, evidence indicates that long-term sustained inhibitory effects on methanogenesis occur in response to dietary supplementation with fat (Grainger and Beauchemin, 2011; Moate et al., 2011), tannins (Grainger et al., 2009), nitrate (van Zijderveld et al., 2011), 3-nitrooxypropanol (Hristov et al., 2015), and 2,2,2-trichloroacetamide (Trei et al., 1971).

In short-term studies of up to $5 \mathrm{wk}$, dietary supplementation with wheat has been shown to reduce $\mathrm{CH}_{4}$ emissions by up to $50 \%$, but in these studies milk fat concentration has been reduced by as much as $40 \%$ (Moate et al., 2012, 2014a, 2017). However, the longterm effects of dietary supplementation with wheat on $\mathrm{CH}_{4}$ emissions, milk fat yields, and fatty acid concentrations in milk fat have not been reported in the scientific literature.

In Australia, the long-term supplementary feeding of wheat to dairy cows is a common practice (Moate et al., 2016). However, before the long-term supplementary feeding of wheat can be recommended as an on-farm feeding strategy to mitigate $\mathrm{CH}_{4}$ emissions, and before the putative $\mathrm{CH}_{4}$ inhibitory effects of wheat feeding can be taken into account in the Australian National Inventory of Greenhouse Gases, the long-term effects of dietary supplementation with wheat on $\mathrm{CH}_{4}$ emissions must be quantified.

The objective of this work was to compare, over 16 wk, the effects of supplementary feeding of diets containing either corn or wheat on milk production, milk fat yield, fatty acid composition of milk fat, and $\mathrm{CH}_{4}$ emissions.

We hypothesized the following:

(1) Cows fed a diet containing corn would initially produce milk with higher milk fat concentration and yield, and emit more $\mathrm{CH}_{4}$ and have a greater $\mathrm{CH}_{4}$ yield than cows fed a similar diet containing wheat.

(2) Mean milk fat concentrations and fatty acid profiles in the milk from cows fed corn- or wheatsupplemented diets would not change between wh 4 and 16 of the experiment.

(3) The relative difference in $\mathrm{CH}_{4}$ yield between the cows fed corn or wheat grain would not diminish between wk 4 and 16 and that the absolute $\mathrm{CH}_{4}$ yields of cows within each treatment would not differ between wk 4 and 16 .

(4) Methane yield of cows would be correlated with the daily nadir in $\mathrm{pH}$ of ruminal fluid.

\section{MATERIALS AND METHODS}

\section{Cows, Experimental Design, and Diets}

Twenty-four multiparous, lactating Holstein-Friesian cows (including 12 ruminally fistulated; $110 \mathrm{~mm}$ internal diameter, Rumen Cannula, www.rumencannula .com) were used in this experiment. At the beginning of the experiment, the cows were producing $36.0 \pm 5.42$ $\mathrm{kg}$ of milk/d (mean \pm SD) and had BW of $549 \pm 36.0$ $\mathrm{kg}$, were $29 \pm 5.8 \mathrm{DIM}$, were $5.3 \pm 2.15 \mathrm{yr}$ of age and had, on average, $3.3 \pm 2.14$ lactations. Cows were cared for according to the Australian Code of Practice for the Care and Use of Animals for Scientific Purposes (NHMRC, 2013). Animal use was approved by the Animal Ethics Committee of the Department of Economic Development Jobs Transport and Resources-Victoria.

The experiment design was a $2 \times 2$ factorial (fistulate $\times$ diet) treatment structure with 6 cows per treatment. The design employed a 4-row $\times 6$-column blocking structure, the rows corresponding to 4 cohort blocks defined according to calving date, block 1 being the 6 earliest calving cows, up to block 4, the 6 latest calving cows, and the 6 columns corresponded to 6 respiration chambers. This design was chosen to allow the cohort blocks of 6 cows to be sequenced through the chambers in calving date order. The design was generated and randomized, using CycDesigN software (VSN International, Hemel Hempstead, UK), such that each of the 4 treatments was replicated 6 times, represented once in each chamber, once or twice in each block, and such that fistulation, rather than diet, was partially confounded with block. It was necessary to swap 2 cows between adjacent calving date blocks to ensure the specified number of fistulated cows occurred in each block.

The diets were the (1) corn diet (CRN) of $10.0 \mathrm{~kg}$ of $\mathrm{DM} / \mathrm{d}$ of crushed corn grain, $1.8 \mathrm{~kg}$ of $\mathrm{DM} / \mathrm{d}$ of canola meal, $0.2 \mathrm{~kg}$ of DM/d of minerals, and $11.0 \mathrm{~kg}$ of DM/d of chopped alfalfa hay; and (2) wheat diet (WHT), which was the same as the CRN diet, except that crushed wheat grain substituted for the crushed corn grain. The chemical compositions of the feeds and mineral mix are shown in Table 1.

\section{Logistics}

Throughout this experiment, the concentrate portion of the diet was offered to the cows separately from 
the hay portion of the diet. The concentrates were individually offered to cows in 2 equal portions during milking (0600 and $1500 \mathrm{~h}$ ), and similarly, after milking, the daily allocation of hay was also offered to the cows in 2 equal portions.

In the 2 wk before the experiment, cows were offered $5 \mathrm{~kg}$ of DM of wheat during milking and about $16 \mathrm{~kg}$ of DM of alfalfa hay per day. Cows were transitioned to their treatment diets on $\mathrm{d} 1$ to 8 , then were offered their full treatment diet for the remainder of the experiment. The availability of only 6 respiration chambers meant that the start of the experiment had to be staggered, with blocks 3 and 4 starting 1 wk later than blocks 1 and 2. Moreover, due to the long duration of the experiment, cows were fed their diets in different places. During d 1-20, 26-62, and 68-104, cows were group fed their alfalfa hay while in an outdoor group pen. During d 21-23, 63-65, and 105-107, cows were individually fed their alfalfa hay in individual feed-stalls within a well-ventilated animal house (Williams et al., 2011). During d 1-23, 26-65, and 68-107, cows were offered the concentrate (grain, canola meal, and minerals) portion of their diet in the dairy during milking. During d 24 and 25, 66 and 67, and 108 and 109, cows were housed in controlled-climate respiration chambers that were used to measure $\mathrm{CH}_{4}$ emissions. While in these chambers, cows were fed the concentrate portion of their ration during milking (0600 to $0630 \mathrm{~h}$ and 1500 to $1530 \mathrm{~h}$ ) and the alfalfa hay after milking. Water was offered ad libitum at all times. Cow BW were measured on $\mathrm{d} 0,26,68$, and 110 of the experiment.

\section{Feed and Milk}

Quantities of the ingredients of the concentrate offered to individual cows were weighed into individual feed bins. Refusals of concentrates were collected and weighed after each feed, with proportions of each grain being assumed to be the same as that offered on a wet basis. Dry matter concentration was determined for representative samples of grains, canola meal, hay, and minerals collected each morning by drying the samples in a forced-draft oven at $105^{\circ} \mathrm{C}$ for $24 \mathrm{~h}$.

Over the course of the experiment, representative samples of corn, wheat, canola meal, and alfalfa hay offered were collected daily, a 100-g sub-sample taken and added to the weekly (Saturday to Friday) bulk sample for each feed type and stored at $-18^{\circ} \mathrm{C}$. These bulked samples were subsequently freeze-dried and ground to pass through a $0.5-\mathrm{mm}$ screen and then analyzed by Dairy One Laboratories (Ithaca, NY) for CP, soluble protein, ADF, NDF, lignin, starch, ash, crude fat (ether extract), $\mathrm{Na}, \mathrm{K}, \mathrm{Ca}, \mathrm{Mg}, \mathrm{P}, \mathrm{Cu}, \mathrm{S}$, and $\mathrm{Cl}$ according to the published chemical analytical procedures of Dairy One (2015), with NFC, TDN, and DCAD calculated according to the procedures of Dairy One (2015). Gross energy was calculated using an equation derived from Klop et al. (2017), and ME was calculated according to NRC (2001).

Cows were milked twice daily, at $\sim 0630$ and $\sim 1530$ $\mathrm{h}$ and yield was measured for each cow at each milking. When cows were not in the chambers, milk yield measurements were recorded using a DeLaval Alpro

Table 1. Composition of main dietary ingredients ( $\mathrm{g} / \mathrm{kg}$ of DM unless otherwise stated)

\begin{tabular}{|c|c|c|c|c|c|}
\hline Parameter & $\begin{array}{l}\text { Crushed } \\
\text { corn }\end{array}$ & $\begin{array}{l}\text { Crushed } \\
\text { wheat }\end{array}$ & $\begin{array}{c}\text { Canola } \\
\text { meal }\end{array}$ & $\begin{array}{l}\text { Mineral } \\
\text { mix }\end{array}$ & Alfalfa \\
\hline $\mathrm{CP}$ & 104 & 129 & 396 & & 197 \\
\hline Soluble protein (\% CP) & 29 & 39 & 22 & & 44 \\
\hline $\mathrm{ADF}$ & 39 & 35 & 181 & & 385 \\
\hline NDF & 89 & 85 & 302 & & 438 \\
\hline Lignin & 11 & 15 & 65 & & 94 \\
\hline NFC & 741 & 747 & 122 & & 249 \\
\hline Starch & 674 & 637 & 6 & & 13 \\
\hline Ash & 17 & 17 & 72 & 596 & 94 \\
\hline TDN & 890 & 860 & 790 & & 560 \\
\hline $\mathrm{Ca}$ & 0.10 & 0.50 & 6.00 & 104.90 & 12.30 \\
\hline $\mathrm{Mg}$ & 1.1 & 1.1 & 5.1 & 111.6 & 2.5 \\
\hline $\mathrm{Na}$ & 0.01 & 0.02 & 0.74 & 0.45 & 0.68 \\
\hline $\mathrm{K}$ & 3.8 & 3.9 & 12.8 & 4.4 & 21.4 \\
\hline $\mathrm{Cl}$ & 0.5 & 1.3 & 0.6 & 6.6 & 5.0 \\
\hline DCAD $(\mathrm{mEq} / 100 \mathrm{~g}$ of $\mathrm{DM})$ & 2.0 & -3.0 & -6.0 & -94.0 & 26 \\
\hline $\mathrm{Cu}(\mathrm{mg} / \mathrm{kg}$ of $\mathrm{DM})$ & 2 & 6 & 4 & 3,440 & 7.0 \\
\hline S & 1.10 & 1.50 & 6.50 & 14.20 & 2.80 \\
\hline Crude fat & 49.0 & 22.0 & 107.0 & & 23.0 \\
\hline Gross energy (MJ/kg of DM) & 18.9 & 18.4 & 20.1 & & 18.4 \\
\hline $\mathrm{ME}(\mathrm{MJ} / \mathrm{kg}$ of $\mathrm{DM})$ & 14.7 & 13.7 & 14.6 & & 8.9 \\
\hline
\end{tabular}


milk metering system (MM25; DeLaval International, Tumba, Sweden) and milk samples for composition analysis were collected from Tuesday afternoon and Wednesday morning milkings. When cows were in the chambers, milk yield measurements were made by collecting and weighing the milk from individual cows. Milk samples (1\% of the yield from individual cows at each milking) were collected, preserved ( $1 \mathrm{M}$ Bronopol; $4 \mathrm{~mL} / \mathrm{L}$ of milk), refrigerated, then bulked over the $2 \mathrm{~d}$ for each cow. From each bulked sample, a 50-mL aliquot was taken and analyzed for fat, protein, and lactose by means of a mid-infrared milk analyzer (model 2000, Bentley Instruments, Chaska, MN). Energy-corrected milk, standardized to $4.0 \%$ fat and $3.3 \%$ protein, was calculated using the following equation (Tyrrell and Reid, 1965):

$$
\begin{gathered}
\text { ECM }(\mathrm{kg} / \text { cow per } \mathrm{d})= \\
\frac{\text { milk yield }(\mathrm{kg}) \times(376 \times \text { fat } \%+209 \times \text { protein } \%+948)}{3,138} .
\end{gathered}
$$

Milk fatty acids were determined by GC-MS analysis of FAME. Total lipid was extracted by the method of Bligh and Dyer (1959) and this was transferred to a 5 -mL glass vial with $2.4 \mathrm{~mL}$ of $6 \% \mathrm{H}_{2} \mathrm{SO}_{4}$ in methanol. Fatty acids were methylated by acid-catalyzed transesterification at $80^{\circ} \mathrm{C}$ for $3 \mathrm{~h}$ (Taylor and Savage, 2006). After cooling to room temperature, FAME were dissolved in hexane containing internal standard (nonadecane, $100 \mathrm{mg} / \mathrm{L}$ ) and analyzed by GC-MS.

Separation of individual FAME was achieved by passing the sample through a Rt-2560 column $(100 \mathrm{~m}$ $\times 0.25 \mathrm{~mm}$ ID, $0.20 \mu \mathrm{m}$ film thickness, Restek, State College, PA) with a constant flow of $1.2 \mathrm{~mL} / \mathrm{min}$ of helium as the carrier gas and the following oven temperature program: initial temperature of $100^{\circ} \mathrm{C}$ and held for $4 \mathrm{~min}$, increased by $6^{\circ} \mathrm{C} / \mathrm{min}$ to $170^{\circ} \mathrm{C}$, and then increased by $2^{\circ} \mathrm{C} / \mathrm{min}$ to $240^{\circ} \mathrm{C}$ and held for $5 \mathrm{~min}$.

The detection was by an Agilent 7000 GC-MS Triple Quad with the following settings: scanning mass range of 40 to $500 \mathrm{amu}$, transfer line temperature of $240^{\circ} \mathrm{C}$, source temperature of $280^{\circ} \mathrm{C}$, Quad temperature of $150^{\circ} \mathrm{C}$, and solvent delay of $11.8 \mathrm{~min}$. A FAME standard mix (Supelco, Bellefonte, PA) and CLA methyl ester standards (Sigma-Aldrich, St. Louis, MO) were used to provide absolute quantification of each FAME.

Total de novo fatty acids were calculated as (C4:0 $+\mathrm{C} 6: 0+\mathrm{C} 8: 0+\mathrm{C} 10: 0+\mathrm{C} 12: 0+\mathrm{C} 14: 0+\mathrm{C} 14: 1$ $+\mathrm{C} 15: 0+0.5 \times \mathrm{C} 16: 0)$. The $\Delta^{9}$-desaturase index for C14:0 (C14D9R) was calculated as cis-9 C14:1/ (C14:0 + cis-9 C14:1), that for C16:0 (C16D9R) was calculated as cis-9 C16:1/(C16:0 + cis-9 C16:1), and the $\Delta^{9}$-desaturase index for C18:0 (C18D9R) was calculated as cis-9 $\mathrm{C} 18: 1 /(\mathrm{C} 18: 0+$ cis-9 C18:1). The mean melting points of milk fats were estimated by the method described by Moate et al. (2017).

\section{Methane Emissions}

Methane emissions from individual cows were measured using 6 open-circuit respiration chambers (No Pollution Industrial Systems, Edinburgh, UK). General characteristics of the chambers have been described by Garner et al. (2016). In the current experiment, air was exhausted from each chamber at $\sim 3,600 \mathrm{~L} / \mathrm{min}$, temperature was $17^{\circ} \mathrm{C}$, and relative humidity was $60 \%$. Calibration of the chambers was performed before and after each 2 -wk period of measurements using the procedures described by Williams et al. (2013).

During the experiment, air was sampled continuously at the common air intake duct and at each chamber's exhaust duct using diaphragm vacuum pumps with 16 L/min flow capacity per head (2107CD18-194, Thomas Pumps \& Compressors, Seven Hills, NSW, Australia). The sample air streams were dried using a multi-tube Nafion dryer (PD-50T-24MSA, Perma Pure, Lakewood, $\mathrm{NJ})$.

The air streams from chambers 1 to 4 were sequenced to an analyzer in a 30-min cycle consisting of $3 \mathrm{~min}$ phases. The phase sequence was air into chamber 1 and 2 , chamber 1 exhaust, chamber 2 exhaust, chamber 3 exhaust, chamber 4 exhaust, air into chamber 3 and 4 , chamber 1 exhaust, chamber 2 exhaust, chamber 3 exhaust, chamber 4 exhaust. Sequencing of the sample streams to the analyzer was controlled by solenoids to ensure a quick response time after switching the air stream. Solenoid control was by a DT80M logger (DataTaker, Scoresby, Victoria, Australia). All air streams passed through a mass-flow controller (Aalborg GFC17, Aalborg Instruments \& Controls Inc., New York, NY) set at $1.1 \mathrm{~L} / \mathrm{min}$ to ensure the instruments received a steady stream of air regardless of pump performance. A multiple tube flow-meter (Aalborg PMR3-010071, Aalborg Instruments \& Controls Inc.) was used to partition the air into 2 sub-streams. One sub-stream $(1,000 \mathrm{~mL} / \mathrm{min})$ was directed to an infrared $\mathrm{CH}_{4}$ sensor (Servomex, Gfx 50 vpm, 0-500 ppm, East Sussex, UK). The other sub-stream (150 $\mathrm{mL} / \mathrm{min}$ ) was directed to an infrared carbon dioxide sensor (Servomex, IR1520 1\%, 0-1\%) which was followed by a paramagnetic oxygen sensor (Servomex, Pm 1158, 0-100\%). All gas sensors were fitted in a Xentra $4100 \mathrm{C} 1$ gas analyzer (Servomex). The oxygen, carbon dioxide and $\mathrm{CH}_{4}$ concentrations, and gas pressure at inlet and exhausts were recorded at 10-s intervals by the DT80M logger (DataTaker).

The air streams from chambers 5 to 8 (chambers 7 and 8 not used in this experiment) were sequenced to 
an analyzer in a 30-min cycle. Sequencing, flow control, sample drying, and partitioning were similar to those used for chambers 1 to 4 . One sub-stream $(1,000$ $\mathrm{mL} / \mathrm{min}$ ) was directed to a $\mathrm{CH}_{4}$ sensor, 1 sub-stream $(150 \mathrm{~mL} / \mathrm{min})$ was directed to a carbon dioxide sensor, and 1 sub-stream $(150 \mathrm{~mL} / \mathrm{min})$ was directed to an oxygen sensor. Gas sensors and their housing were of the same specification as used for chambers 1 to 4 . Data were recorded at 10-s intervals by a DT80 logger (DataTaker).

Temperature and relative humidity of the air entering and leaving the chambers as well as air circulation and exhaust rate were recorded by the system control software (Metasys, Johnson Controls, Milwaukee, WI).

\section{Ruminal Fermentation}

Ruminal fluid samples ( $\sim 400 \mathrm{~mL})$ were collected from cows after the morning feeding period on $\mathrm{d} 26,68$, and 110 between 1100 to $1145 \mathrm{~h}$, which was approximately $4 \mathrm{~h}$ after cows had exited the chambers. Ruminal fluid samples were collected from rumen-fistulated and nonfistulated cows using a sampling tube and a vacuum pump (Moate et al., 2014b). The $\mathrm{pH}$ of the ruminal fluid was immediately measured using a Cyberscan 300 pH meter (Eutech, Thermo Fisher Scientific Inc., Waltham, MA). A 4.0-mL sub-sample of ruminal fluid was diluted with $1 \mathrm{~mL}$ of $25 \%$ orthophosphoric acid, then frozen for subsequent analysis of VFA, according to the GC method of Packer et al. (2011). The concentrations of D- and L-lactate in ruminal fluid were measured according to the method of Gawehn (1988). A $0.40-\mathrm{mL}$ sub-sample of ruminal fluid was diluted with $3.60 \mathrm{~mL}$ of $0.1 \mathrm{M} \mathrm{HCl}$ and stored at $-18^{\circ} \mathrm{C}$ until analyzed for ammonia by a spectrophotometric method as previously described (Moate et al., 2017).

During the period when cows were in chambers, the ruminal fluid in fistulated cows was continuously monitored for $\mathrm{pH}$ by intra-ruminal boli (KB5, Kahne Limited, Auckland, New Zealand), which were fitted with a 750-g weight so they resided at the bottom of the rumen. Any drift in $\mathrm{pH}$ measurements by individual boli in the period between inserting and removal from the rumen was corrected for by linear interpolation. The data for each cow were logged over $2 \mathrm{~d}$. These data were first averaged for 15-min intervals, and then the data for the corresponding intervals over the $2 \mathrm{~d}$ were averaged for each cow to produce a 24 -h diurnal pattern of ruminal fluid $\mathrm{pH}$ for each cow. Data were then summarized as average duration below $\mathrm{pH} 6$, average area below $\mathrm{pH} 6$, average time to nadir after AM feed and after PM feed, average nadir $\mathrm{pH}$ after $\mathrm{AM}$ feed and after $\mathrm{PM}$ feed, mean $\mathrm{pH}$, average minimum, average maximum $\mathrm{pH}$, and average $\mathrm{pH}$ range.

\section{Statistical Analyses}

Methane and production data were summarized for each cow within each 2-d chamber period (i.e., during wk 4, 10, and 16) by taking the simple mean of each variable. The resulting data were analyzed by ANOVA using GenStat 18 software (VSN International Ltd., Hemel Hempstead, UK), specifying an additive treatment structure of fistulation status plus dietary treatment, crossed with week, and a factorial blocking structure of calving-cohort by chamber, split for week. Two fistulated cows (one in each treatment), and a nonfistulated cow from the WHT treatment had to be removed early in the experiment due to mastitis (unrelated to treatments), and these were included in the analysis as missing values. The BW data were analyzed by analysis of covariance with a model structure similar to that used in the above ANOVA, but BW on day zero was included as a covariate. For $\mathrm{pH}$ bolus data, confined to fistulated cows, data were analyzed by mixed model using ReML software in GenStat 18 with fixed effects for calving-cohort, chamber, and factorial dietary treatment by week, and random effects for animal split for week.

For analysis of the relationship between $\mathrm{CH}_{4}$ yield and milk fat concentration, a regression analysis was performed using REML in GenStat with fixed linear effects of fat by diet, and repeated measures random effects of week within cow.

Distributional assumptions of normality and constant variance were examined graphically using histograms and normal quantile plots of residuals, and plots of residuals against fitted values. Data were transformed using an arcsine transformation (percentages of milk fatty acids) as indicated by the residual plots. Means were back-transformed to the original scale for presentation. Significant differences between means were considered to have occurred when $P<0.05$, and a trend when 0.05 $<P<0.1$

\section{RESULTS}

\section{Overall Responses of Cows}

Mean DMI of each feed, total DMI, and mean intakes of CP, NDF, starch, fat, and gross energy, as well as the concentration of grain in each diet at wk 4, 10, and 16, are shown in Table 2. Cows offered the CRN diet ate $0.6 \mathrm{~kg}$ of $\mathrm{DM} / \mathrm{d}$ more alfalfa hay than cows offered the WHT diet, and this contributed to the $1.0 \mathrm{~kg} / \mathrm{d}$ greater total DMI in cows offered the CRN diet compared with the cows offered the WHT diet. Means for yields of milk, ECM, milk fat, milk protein, and milk lactose, as well as mean concentrations in milk of fat, protein, and lactose, are also shown in Table 2. Cows offered the 


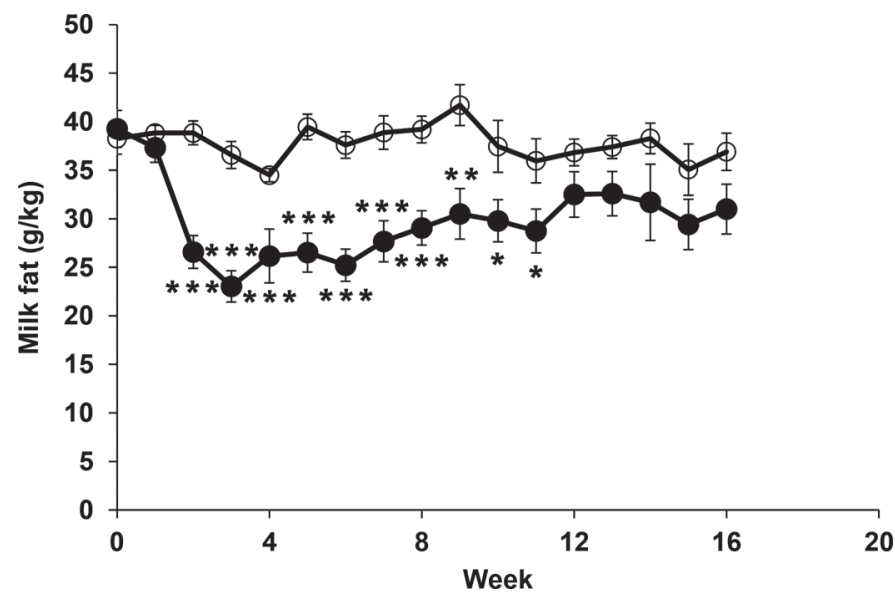

Figure 1. Mean concentrations $( \pm \mathrm{SEM})$ of milk fat over $16 \mathrm{wk}$, in the milk of cows fed either the corn $\operatorname{diet}(\mathrm{O})$ or the wheat $\operatorname{diet}(-)$ Significance is defined by ${ }^{*} P<0.05,{ }^{* *} P<0.01$, and ${ }^{* * *} P<0.001$.
CRN diet produced $31.2 \mathrm{~kg} / \mathrm{d}$ of milk, which was less than the $34.5 \mathrm{~kg} / \mathrm{d}$ of milk produced by cows offered the WHT diet, but diet did not affect ECM. Cows fed the CRN diet produced similar amounts of milk fat at wk 4,10 , and 16 . However, at wk 4 , cows fed the CRN diet produced more milk fat than cows fed the WHT diet, but this effect had disappeared by wk 10. This fat effect at wk 4, was associated with a greater milk fat concentration in the milk of cows fed the CRN diet compared with the milk fat concentration in the milk of cows fed the WHT diet, but based on the mean data shown in Figure 1, this effect on milk fat concentration had disappeared by wk 12 .

Over the 16 wk of the experiment, no effects of diet on concentrations of milk protein or lactose were observed. Diet did not influence milk protein yield at wk 4 and 10, but at wk 16, cows fed the CRN diet produced less milk protein than cows fed the WHT diet, and over the $16 \mathrm{wk}$ of the experiment, the protein yield of the cows offered the CRN diet was less than the protein yield of cows offered the WHT diet (0.97 vs. $1.08 \mathrm{~kg} / \mathrm{d})$.

Table 2. Feed intake, milk yield, milk composition, and BW from cows on each treatment ${ }^{1}$ during wk 4,10 , and 16 of the experiment

\begin{tabular}{|c|c|c|c|c|c|c|c|c|c|c|c|}
\hline \multirow[b]{2}{*}{ Parameter } & \multicolumn{2}{|c|}{ Wk 4} & \multicolumn{2}{|c|}{ Wk 10} & \multicolumn{2}{|c|}{ Wk 16} & \multirow[b]{2}{*}{$\mathrm{SEM}_{\mathrm{T}}{ }^{2}$} & \multirow[b]{2}{*}{$\mathrm{SEM}_{\mathrm{W}}{ }^{3}$} & \multicolumn{3}{|c|}{$P$-value } \\
\hline & $\mathrm{CRN}$ & WHT & $\mathrm{CRN}$ & WHT & $\mathrm{CRN}$ & WHT & & & $\mathrm{TRT}^{4}$ & Week & TRT $\times$ week \\
\hline No. of cows & 11 & 10 & 11 & 10 & 11 & 10 & & & & & \\
\hline \multicolumn{12}{|l|}{ Feed intake ${ }^{5}(\mathrm{~kg}$ of $\mathrm{DM} / \mathrm{d})$} \\
\hline Alfalfa hay & $10.0^{\mathrm{b}}$ & $8.9^{\mathrm{a}}$ & $10.3^{\mathrm{b}}$ & $9.8^{\mathrm{b}}$ & $10.4^{\mathrm{b}}$ & $10.1^{\mathrm{b}}$ & 0.23 & 0.15 & 0.049 & 0.001 & 0.021 \\
\hline Corn & 9.9 & 0 & 10.0 & 0 & 9.9 & 0 & & & & & \\
\hline Wheat & 0 & 9.8 & 0 & 9.0 & 0 & 9.9 & & & & & \\
\hline Canola meal & 1.8 & 1.8 & 1.8 & 1.8 & 1.8 & 1.8 & 0.01 & 0.01 & 0.932 & 0.211 & 0.663 \\
\hline Minerals & 0.2 & 0.2 & 0.2 & 0.2 & 0.2 & 0.2 & 0.001 & 0.001 & 0.939 & 0.467 & 0.542 \\
\hline Total & $21.9^{\mathrm{b}}$ & $20.7^{\mathrm{a}}$ & $22.4^{\mathrm{b}}$ & $20.8^{\mathrm{a}}$ & $22.3^{\mathrm{b}}$ & $22.1^{\mathrm{b}}$ & 0.24 & 0.19 & 0.003 & 0.001 & 0.005 \\
\hline Total CP & 3.7 & 3.8 & 3.8 & 3.8 & 3.9 & 3.9 & 0.05 & 0.04 & 0.732 & 0.001 & 0.608 \\
\hline Total NDF & $5.6^{\mathrm{a}}$ & $5.6^{\mathrm{a}}$ & $5.8^{\mathrm{ab}}$ & $5.8^{\mathrm{ab}}$ & $6.0^{\mathrm{b}}$ & $5.8^{\mathrm{ab}}$ & 0.12 & 0.07 & 0.603 & 0.001 & 0.263 \\
\hline Total starch & $6.7^{\mathrm{b}}$ & $6.6^{\mathrm{ab}}$ & $6.6^{\mathrm{ab}}$ & $6.2^{\mathrm{a}}$ & $6.7^{\mathrm{b}}$ & $6.6^{\mathrm{b}}$ & 0.12 & 0.13 & 0.267 & 0.008 & 0.281 \\
\hline Total fat & 0.80 & 0.73 & 0.81 & 0.73 & 0.82 & 0.74 & 0.047 & 0.006 & 0.272 & 0.006 & 0.881 \\
\hline $\mathrm{GEI}^{6}(\mathrm{MJ} / \mathrm{d})$ & $396^{\mathrm{ab}}$ & $394^{\mathrm{a}}$ & $403^{\mathrm{abc}}$ & $397^{\mathrm{abc}}$ & $415^{\mathrm{c}}$ & $406^{\mathrm{bc}}$ & 6.3 & 3.8 & 0.452 & 0.001 & 0.727 \\
\hline Grain $^{7}(\mathrm{~g} / \mathrm{kg})$ & $454^{\mathrm{b}}$ & $476^{\mathrm{c}}$ & $449^{\mathrm{ab}}$ & $432^{\mathrm{a}}$ & $445^{\mathrm{ab}}$ & $451^{\mathrm{b}}$ & 6.0 & 4.3 & 0.610 & 0.001 & 0.001 \\
\hline Milk yield (kg/d) & $32.9^{\mathrm{bc}}$ & $35.2^{\mathrm{c}}$ & $30.8^{\mathrm{ab}}$ & $33.9^{b c}$ & $29.9^{\mathrm{a}}$ & $34.3^{\mathrm{c}}$ & 1.10 & 0.47 & 0.047 & 0.001 & 0.090 \\
\hline $\mathrm{ECM}$ & 31.7 & 27.6 & 29.5 & 29.5 & 28.2 & 30.3 & 1.30 & 0.50 & 0.722 & 0.777 & 0.001 \\
\hline Fat & $1.24^{\mathrm{b}}$ & $0.80^{\mathrm{a}}$ & $1.15^{\mathrm{b}}$ & $1.02^{\mathrm{b}}$ & $1.09^{\mathrm{b}}$ & $1.07^{\mathrm{b}}$ & 0.074 & 0.036 & 0.066 & 0.171 & 0.001 \\
\hline Protein & $1.03^{\mathrm{bc}}$ & $1.11^{\mathrm{c}}$ & $0.97^{\mathrm{ab}}$ & $1.07^{\mathrm{bc}}$ & $0.92^{\mathrm{a}}$ & $1.08^{\mathrm{c}}$ & 0.035 & 0.016 & 0.030 & 0.001 & 0.056 \\
\hline Lactose & $1.71^{\mathrm{b}}$ & $1.83^{\mathrm{b}}$ & $1.61^{\mathrm{a}}$ & $1.79^{\mathrm{b}}$ & $1.58^{\mathrm{a}}$ & $1.81^{\mathrm{b}}$ & 0.055 & 0.029 & 0.033 & 0.017 & 0.136 \\
\hline \multicolumn{12}{|l|}{ Milk composition (g/kg) } \\
\hline Fat & $37.9^{\mathrm{d}}$ & $22.9^{\mathrm{a}}$ & $37.6^{\mathrm{d}}$ & $30.2^{\mathrm{b}}$ & $36.7^{\mathrm{cd}}$ & $31.7^{\mathrm{bc}}$ & 1.83 & 1.19 & 0.002 & 0.004 & 0.001 \\
\hline Protein & 31.3 & 31.6 & 31.4 & 31.6 & 30.7 & 31.5 & 0.53 & 0.23 & 0.562 & 0.210 & 0.421 \\
\hline Lactose & 51.7 & 52.0 & 52.3 & 52.8 & 52.8 & 52.9 & 0.52 & 0.30 & 0.633 & 0.010 & 0.746 \\
\hline $\mathrm{BW}^{8}(\mathrm{~kg})$ & $561^{\mathrm{a}}$ & $574^{\mathrm{ab}}$ & $576^{\mathrm{bc}}$ & $590^{\mathrm{cd}}$ & $588^{\text {bcd }}$ & $598^{\mathrm{d}}$ & 5.1 & 2.6 & 0.067 & 0.001 & 0.696 \\
\hline
\end{tabular}

\footnotetext{
${ }^{\mathrm{a}-\mathrm{d}}$ Means in the same row followed by different superscripts differ significantly $(P<0.05)$.

${ }^{1} \mathrm{CRN}=$ corn diet; WHT $=$ wheat diet.

${ }^{2} \mathrm{SEM}_{\mathrm{T}}=$ standard error of the mean for comparisons of treatments within weeks.

${ }^{3} \mathrm{SEM}_{\mathrm{w}}=$ standard error of the mean for comparisons between weeks within treatments.

${ }^{4} \mathrm{TRT}=$ treatment.

${ }^{5}$ Mean feed intake measured while cows were in respiration chambers and the day prior.

${ }^{6} \mathrm{GEI}=$ gross energy intake.

${ }^{7}$ The concentration of either corn or wheat in each diet.

${ }^{8}$ Covariate-corrected BW with individual cow BW $(549 \pm 36.0 \mathrm{~kg})$ on d 0 as the covariate.
} 
Similarly, although there was no effect of diet on milk lactose production at wk 4 , at wk 10 and 16 , and over the 16 wk of the experiment, cows fed the CRN diet produced less milk lactose than cows fed the WHT diet.

Mean concentrations for individual fatty acids, the $\Delta^{9}$-desaturase indexes for C14:0, C16:0, and C18:0 and the estimated mean melting points of the fatty acids for each diet at wk 4, 10, and 16 are shown in Table 3. Of the 19 major fatty acids listed in Table 3, diet caused main effect differences for 16 of the fatty acids. The exceptions were C10:0 $(P=0.098), \mathrm{C} 12: 0, \mathrm{C} 14: 0$ and cis-9,trans-11 C18:2. For 6 of the fatty acids (C6:0, C8:0, C15:0, trans-10 C18:1, C18:2, and trans-10,cis-12 C18:2) that were influenced by diet, a difference was present at wk 4, but the difference was not present at wk 16. At wk 4, the milk fat from cows fed the CRN diet had greater concentrations of total SFA and lower concentrations of MUFA and PUFA than the milk fat from cows fed the WHT diet. However, by wk 16, no differences were observed between these parameters in the milk fat of cows fed both diets. At wk 4, the C14D9R was smaller in the milk fat of cows fed the CRN diet compared with the WHT diet. At wk 4 and 10, the C16D9R were smaller in the milk fat of cows fed the CRN diet compared with the WHT diet, whereas at wk 4, 10, and 16, the C18D9R was greater in the milk fat of cows fed the CRN diet than in the milk fat of cows fed the WHT diet. In cows fed the WHT diet, the magnitudes of all $3 \Delta^{9}$-desaturase indexes declined after wk 4 . At wk 16, the estimated melting point of fatty acids was less for cows fed the CRN diet compared with that of cows fed the WHT diet.

Table 3. Means of individual milk fatty acids ( $\mathrm{g} / 100 \mathrm{~g}$ of total fatty acids unless otherwise stated); the $\Delta^{9}$-desaturase ratios for C14:0, C16:0, and C18:0; and the melting point of milk fatty acids from cows offered each treatment ${ }^{1}$ during wk 4,10 , and 16 of the experiment

\begin{tabular}{|c|c|c|c|c|c|c|c|c|c|c|c|}
\hline \multirow[b]{2}{*}{ Parameter } & \multicolumn{2}{|c|}{ Wk 4} & \multicolumn{2}{|c|}{ Wk 10} & \multicolumn{2}{|c|}{ Wk 16} & \multirow[b]{2}{*}{$\mathrm{SEM}_{\mathrm{T}}{ }^{2}$} & \multirow[b]{2}{*}{$\mathrm{SEM}_{W}{ }^{3}$} & \multicolumn{3}{|c|}{$P$-value } \\
\hline & $\mathrm{CRN}$ & WHT & CRN & WHT & CRN & WHT & & & $\mathrm{TRT}^{4}$ & Week & TRT $\times$ week \\
\hline No. of cows & 11 & 10 & 11 & 10 & 11 & 10 & & & & & \\
\hline $\mathrm{C} 4: 0$ & $2.14^{\mathrm{c}}$ & $1.37^{\mathrm{a}}$ & $1.86^{\mathrm{b}}$ & $1.56^{\mathrm{a}}$ & $2.28^{\mathrm{c}}$ & $1.83^{\mathrm{b}}$ & 0.095 & 0.080 & 0.001 & 0.001 & 0.017 \\
\hline C6:0 & $2.08^{\mathrm{d}}$ & $1.25^{\mathrm{a}}$ & $1.77^{\mathrm{b}}$ & $1.42^{\mathrm{a}}$ & $2.03^{\mathrm{cd}}$ & $1.80^{\mathrm{bc}}$ & 0.084 & 0.064 & 0.001 & 0.001 & 0.001 \\
\hline C8:0 & $1.34^{\mathrm{c}}$ & $0.85^{\mathrm{a}}$ & $1.11^{\mathrm{b}}$ & $0.87^{\mathrm{a}}$ & $1.35^{\mathrm{c}}$ & $1.23^{\mathrm{bc}}$ & 0.056 & 0.040 & 0.002 & 0.001 & 0.001 \\
\hline C10:0 & $2.96^{\mathrm{b}}$ & $2.27^{\mathrm{a}}$ & $2.56^{\mathrm{a}}$ & $2.27^{\mathrm{a}}$ & $3.07^{\mathrm{b}}$ & $3.18^{\mathrm{b}}$ & 0.137 & 0.095 & 0.098 & 0.001 & 0.001 \\
\hline C12:0 & $3.27^{\mathrm{ab}}$ & $3.14^{\mathrm{a}}$ & $8.12^{\mathrm{d}}$ & $7.27^{\mathrm{c}}$ & $3.38^{\mathrm{ab}}$ & $3.91^{\mathrm{b}}$ & 0.206 & 0.137 & 0.559 & 0.001 & 0.001 \\
\hline C14:0 & $11.2^{\mathrm{a}}$ & $11.5^{\mathrm{a}}$ & $25.9^{\mathrm{d}}$ & $23.3^{\mathrm{c}}$ & $12.3^{\mathrm{ab}}$ & $13.9^{\mathrm{b}}$ & 0.590 & 0.486 & 0.687 & 0.001 & 0.001 \\
\hline $\mathrm{C} 14: 1$ cis-9 & $1.06^{\mathrm{ab}}$ & $2.55^{\mathrm{d}}$ & $0.93^{\mathrm{a}}$ & $1.43^{\mathrm{b}}$ & $1.19^{\mathrm{ab}}$ & $1.83^{\mathrm{c}}$ & 0.148 & 0.109 & 0.001 & 0.001 & 0.001 \\
\hline C15:0 & $1.20^{\mathrm{b}}$ & $2.69^{\mathrm{d}}$ & $0.96^{\mathrm{a}}$ & $1.68^{\mathrm{c}}$ & $1.41^{\mathrm{bc}}$ & $1.74^{\mathrm{c}}$ & 0.127 & 0.071 & 0.001 & 0.001 & 0.001 \\
\hline $\mathrm{C} 16: 0$ & $31.4^{\mathrm{bc}}$ & $33.1^{\mathrm{c}}$ & $24.4^{\mathrm{a}}$ & $29.2^{\mathrm{b}}$ & $31.3^{\mathrm{bc}}$ & $36.1^{\mathrm{d}}$ & 0.977 & 0.642 & 0.009 & 0.001 & 0.029 \\
\hline $\mathrm{C} 16: 1$ cis-9 & $1.51^{\mathrm{ab}}$ & $3.30^{\mathrm{d}}$ & $1.19^{\mathrm{a}}$ & $2.07^{\mathrm{bc}}$ & $1.60^{\mathrm{ab}}$ & $2.54^{\mathrm{c}}$ & 0.241 & 0.150 & 0.002 & 0.001 & 0.007 \\
\hline C17:0 & $0.97^{\mathrm{bc}}$ & $1.94^{\mathrm{d}}$ & $0.66^{\mathrm{a}}$ & $1.20^{\mathrm{c}}$ & $0.85^{\mathrm{ab}}$ & $1.16^{\mathrm{c}}$ & 0.079 & 0.059 & 0.001 & 0.001 & 0.001 \\
\hline C18:0 & $12.78^{\mathrm{f}}$ & $3.97^{\mathrm{a}}$ & $9.01^{\mathrm{d}}$ & $4.93^{\mathrm{b}}$ & $11.58^{\mathrm{e}}$ & $6.39^{\mathrm{c}}$ & 0.478 & 0.264 & 0.001 & 0.001 & 0.001 \\
\hline C18:1 cis-9 & $22.1^{\mathrm{c}}$ & $18.3^{\mathrm{b}}$ & $16.3^{\mathrm{ab}}$ & $16.1^{\mathrm{a}}$ & $21.4^{\mathrm{c}}$ & $16.7^{\mathrm{ab}}$ & 0.816 & 0.583 & 0.012 & 0.001 & 0.001 \\
\hline C18:1 trans -10 & $1.69^{\mathrm{a}}$ & $6.76^{\mathrm{b}}$ & $1.72^{\mathrm{a}}$ & $2.09^{\mathrm{a}}$ & $1.90^{\mathrm{a}}$ & $2.50^{\mathrm{a}}$ & 0.405 & 0.354 & 0.001 & 0.001 & 0.001 \\
\hline $\mathrm{C} 18: 2 \mathrm{n}-6$ & $1.99^{\mathrm{ab}}$ & $3.34^{\mathrm{c}}$ & $1.62^{\mathrm{a}}$ & $2.01^{\mathrm{ab}}$ & $2.08^{\mathrm{b}}$ & $2.42^{\mathrm{b}}$ & 0.150 & 0.096 & 0.003 & 0.001 & 0.001 \\
\hline CLA cis-9,trans-11 & $0.25^{\mathrm{a}}$ & $0.40^{\mathrm{b}}$ & $0.19^{\mathrm{a}}$ & $0.25^{\mathrm{a}}$ & $0.30^{\mathrm{ab}}$ & $0.29^{\mathrm{ab}}$ & 0.042 & 0.038 & 0.123 & 0.022 & 0.119 \\
\hline $\begin{array}{l}\text { CLA trans }-10, \text { cis }-12 \\
(\mathrm{mg} / \mathrm{kg})\end{array}$ & $521^{\mathrm{a}}$ & $976^{\mathrm{b}}$ & $430^{\mathrm{a}}$ & $597^{\mathrm{a}}$ & $467^{\mathrm{a}}$ & $554^{\mathrm{a}}$ & 61.1 & 54.7 & 0.003 & 0.001 & 0.005 \\
\hline C18:3n-3 & $0.42^{\mathrm{b}}$ & $0.83^{\mathrm{e}}$ & $0.28^{\mathrm{a}}$ & $0.55^{\mathrm{c}}$ & $0.41^{\mathrm{b}}$ & $0.69^{\mathrm{d}}$ & 0.039 & 0.030 & 0.001 & 0.001 & 0.046 \\
\hline $\mathrm{C} 20: 0$ & $0.15^{\mathrm{c}}$ & $0.08^{\mathrm{a}}$ & $0.16^{\mathrm{c}}$ & $0.12^{\mathrm{b}}$ & $0.19^{\mathrm{d}}$ & $0.12^{\mathrm{b}}$ & 0.006 & 0.004 & 0.001 & 0.001 & 0.005 \\
\hline Total other fatty acids & $1.46^{\mathrm{ab}}$ & $2.32^{\mathrm{c}}$ & $1.22^{\mathrm{a}}$ & $1.64^{\mathrm{b}}$ & $1.45^{\mathrm{ab}}$ & $1.68^{\mathrm{b}}$ & 0.123 & 0.097 & 0.004 & 0.001 & 0.008 \\
\hline Total SFA & $70.6^{\mathrm{b}}$ & $64.7^{\mathrm{a}}$ & $77.5^{\mathrm{d}}$ & $75.2^{\mathrm{cd}}$ & $70.9^{\mathrm{b}}$ & $73.1^{\mathrm{bc}}$ & 1.26 & 0.89 & 0.209 & 0.001 & 0.001 \\
\hline Total MUFA & $27.8^{\mathrm{c}}$ & $33.2^{\mathrm{d}}$ & $21.3^{\mathrm{a}}$ & $23.3^{\mathrm{ab}}$ & $27.5^{\mathrm{c}}$ & $25.3^{\mathrm{bc}}$ & 1.14 & 0.86 & 0.204 & 0.001 & 0.001 \\
\hline Total PUFA & $2.71^{\mathrm{b}}$ & $4.67^{\mathrm{d}}$ & $2.13^{\mathrm{a}}$ & $2.86^{\mathrm{bc}}$ & $2.84^{\mathrm{bc}}$ & $3.45^{\mathrm{c}}$ & 0.210 & 0.123 & 0.002 & 0.001 & 0.001 \\
\hline Total DNFA ${ }^{5}$ & $41.7^{\mathrm{a}}$ & $43.8^{\mathrm{a}}$ & $56.0^{\mathrm{c}}$ & $55.4^{\mathrm{c}}$ & $43.4^{\mathrm{a}}$ & $48.7^{\mathrm{b}}$ & 0.90 & 0.68 & 0.048 & 0.001 & 0.001 \\
\hline C14D9R ${ }^{6}$ & $0.086^{\mathrm{b}}$ & $0.179^{\mathrm{d}}$ & $0.035^{\mathrm{a}}$ & $0.060^{\mathrm{ab}}$ & $0.088^{\mathrm{bc}}$ & $0.117^{\mathrm{c}}$ & 0.0093 & 0.0068 & 0.001 & 0.001 & 0.001 \\
\hline $\mathrm{C}^{16 \mathrm{D} 9 \mathrm{R}^{7}}$ & $0.046^{\mathrm{ab}}$ & $0.090^{\mathrm{d}}$ & $0.046^{\mathrm{a}}$ & $0.066^{\mathrm{bc}}$ & $0.048^{\mathrm{abc}}$ & $0.067^{\mathrm{c}}$ & 0.0063 & 0.0043 & 0.004 & 0.015 & 0.009 \\
\hline C18D9R ${ }^{8}$ & $0.63^{\mathrm{a}}$ & $0.83^{\mathrm{d}}$ & $0.64^{\mathrm{a}}$ & $0.76^{\mathrm{c}}$ & $0.65^{\mathrm{a}}$ & $0.72^{\mathrm{b}}$ & 0.016 & 0.008 & 0.001 & 0.001 & 0.001 \\
\hline Melting point $\left({ }^{\circ} \mathrm{C}\right)$ & $41.7^{\mathrm{ab}}$ & $43.0^{\mathrm{bc}}$ & $44.3^{\mathrm{de}}$ & $44.7^{\mathrm{e}}$ & $41.6^{\mathrm{a}}$ & $43.5^{\mathrm{cd}}$ & 0.40 & 0.27 & 0.038 & 0.001 & 0.038 \\
\hline
\end{tabular}

\footnotetext{
${ }^{\mathrm{a}-\mathrm{f}}$ Means in the same row followed by different superscripts differ significantly $(P<0.05)$.

${ }^{1} \mathrm{CRN}=$ corn diet; WHT $=$ wheat diet.

${ }^{2} \mathrm{SEM}_{\mathrm{T}}=$ standard error of the mean for comparisons of treatments within weeks.

${ }^{3} \mathrm{SEM}_{\mathrm{w}}=$ standard error of the mean for comparisons between weeks within treatments.

${ }^{4} \mathrm{TRT}=$ treatment.

${ }^{5} \mathrm{DNFA}=$ de novo fatty acids $=\Sigma(\mathrm{C} 4: 0+\mathrm{C} 6: 0+\mathrm{C} 8: 0+\mathrm{C} 10: 0+\mathrm{C} 12: 0+\mathrm{C} 14: 0+\mathrm{C} 14: 1+\mathrm{C} 15: 0+0.5 \times \mathrm{C} 16: 0)$.

${ }^{6} \mathrm{C} 14 \mathrm{D} 9 \mathrm{R}=\Delta^{9}$-desaturase index for C14:0 calculated as $\mathrm{C} 14: 1$ cis-9/(C14:0 + C14:1 cis-9).

${ }^{7} \mathrm{C} 16 \mathrm{D} 9 \mathrm{R}=\Delta^{9}$-desaturase index for $\mathrm{C} 16: 0$ calculated as $\mathrm{C} 16: 1$ cis-9/(C16:0 + C16:1 cis-9).

${ }^{8} \mathrm{C} 18 \mathrm{D} 9 \mathrm{R}=\Delta^{9}$-desaturase index for $\mathrm{C} 18: 0$ calculated as $\mathrm{C} 18: 1$ cis-9/(C18:0 + C18:1 cis-9).
} 
Table 4. Influence of diet on $\mathrm{CH}_{4}$ emissions, $\mathrm{CH}_{4}$ yield, $\mathrm{CH}_{4}$ intensity, and $\mathrm{CH}_{4}$ emissions as a percentage of gross energy intake (GEI) at wk 4,10 , and 16 of the experiment ${ }^{1}$

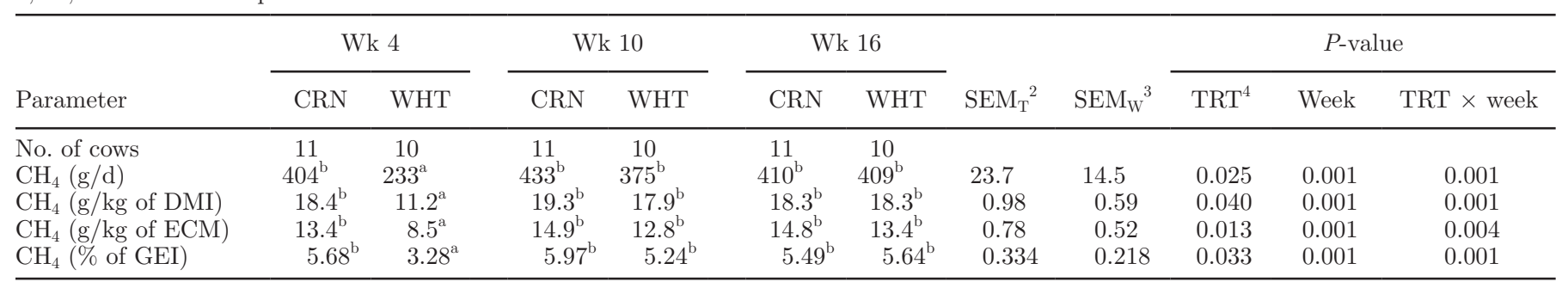

\footnotetext{
${ }^{\mathrm{a}, \mathrm{b}}$ Means in the same row followed by different superscripts differ significantly $(P<0.05)$.

${ }^{1} \mathrm{CRN}=$ corn diet, WHT $=$ wheat diet.

${ }^{2} \mathrm{SEM}_{\mathrm{T}}=$ standard error of the mean for comparisons of treatments within weeks.

${ }^{3} \mathrm{SEM}_{\mathrm{w}}=$ standard error of the mean for comparisons between weeks within treatments.

${ }^{4} \mathrm{TRT}=$ treatment.
}

The effects of diet and duration of feeding on $\mathrm{CH}_{4}$ parameters are shown in Table 4. At wk 4, cows fed the CRN diet emitted more $\mathrm{CH}_{4}\left(\mathrm{~g}\right.$ of $\mathrm{CH}_{4} / \mathrm{d}$ ), had a greater $\mathrm{CH}_{4}$ yield (g of $\mathrm{CH}_{4} / \mathrm{kg}$ of DMI), had greater $\mathrm{CH}_{4}$ intensity (g of $\mathrm{CH}_{4} / \mathrm{kg}$ of ECM), and lost more ingested energy as $\mathrm{CH}_{4}$ (\% gross energy intake) than cows fed the WHT diet. However, these differences between means were not present at wk 10 and 16 .

The relationships between $\mathrm{CH}_{4}$ yields and milk fat concentrations for cows fed the CRN and WHT diets are shown in Figure 2. For cows fed the CRN diet, no significant relationship was observed between $\mathrm{CH}_{4}$ yield and milk fat concentration. However, for cows fed the WHT diet, a positive relationship was observed between milk fat concentration and $\mathrm{CH}_{4}$ yield. Moreover, the slope of the regression line for $\mathrm{CH}_{4}$ yield versus milk fat concentration for cows fed the $\mathrm{CRN}$ diet was 0.03 \pm 0.054 , which was different from the slope for cows fed the WHT diet $(0.64 \pm 0.042)$. Across all cows and weeks, a negative correlation $(\mathrm{r}=-0.640)$ was observed between the concentrations of trans-10 C18:1 and total milk fat concentration and also between trans-10, cis-12 C18:2 and total milk fat concentration $(\mathrm{r}=-0.587$; data not shown).

The effects of diet and duration of feeding on mean $\mathrm{pH}$ in ruminal fluid, and on various metabolites in ruminal fluid (measured in a single sample collected $4 \mathrm{~h}$ after feeding) are shown in Table 5. During wk 4 and 16 , the $\mathrm{pH}$ in ruminal fluid from cows fed the CRN diet was greater than that in cows fed the WHT diet. In Figure 3, the mean circadian patterns of ruminal fluid $\mathrm{pH}$ (as measured by intra-ruminal boli) are shown for cows fed the CRN and WHT diets during wk 4, 10, and 16, while the cows were in the respiration chambers. These data are also summarized in Table 6. Although some diet effects were observed on $\mathrm{pH}$ at $4 \mathrm{~h}$ postfeeding as reported in Table 5, overall, as shown in Table 6, no differences were present between diets with respect to mean $\mathrm{pH}$, minimum $\mathrm{pH}$, maximum $\mathrm{pH}$, duration below $\mathrm{pH}$ 6, and area below $\mathrm{pH}$ 6. Also shown in Figure 3 are the simultaneous mean measurements on $\mathrm{CH}_{4}$ flux. During wk 4, cows fed the CRN diet had greater ammonia concentrations than those fed the WHT diet, but at wk 10 and 16, the reverse occurred. At wk 4 and 10, cows fed the CRN diet had smaller total VFA concentrations than cows fed the WHT diet, but no difference was present at wk 16 (Table 5). During wk 4, 10, and 16, the CRN-fed cows had greater molar \% concentrations of acetic acid and smaller molar \% concentrations of propionic acid than cows fed the WHT diet. Similarly, diet had marked effects on the concentrations of other VFA, but no effect was observed of diet on concentrations of both D- and L-lactate in the ruminal fluid. There were interactions between treatment and week for the molar percentage concentrations of acetic, propionic, n-butyric, isovaleric, n-valeric, and hexaenoic acids as well as for the acetate:propionate $(\mathrm{A}: \mathbf{P})$ ratio.

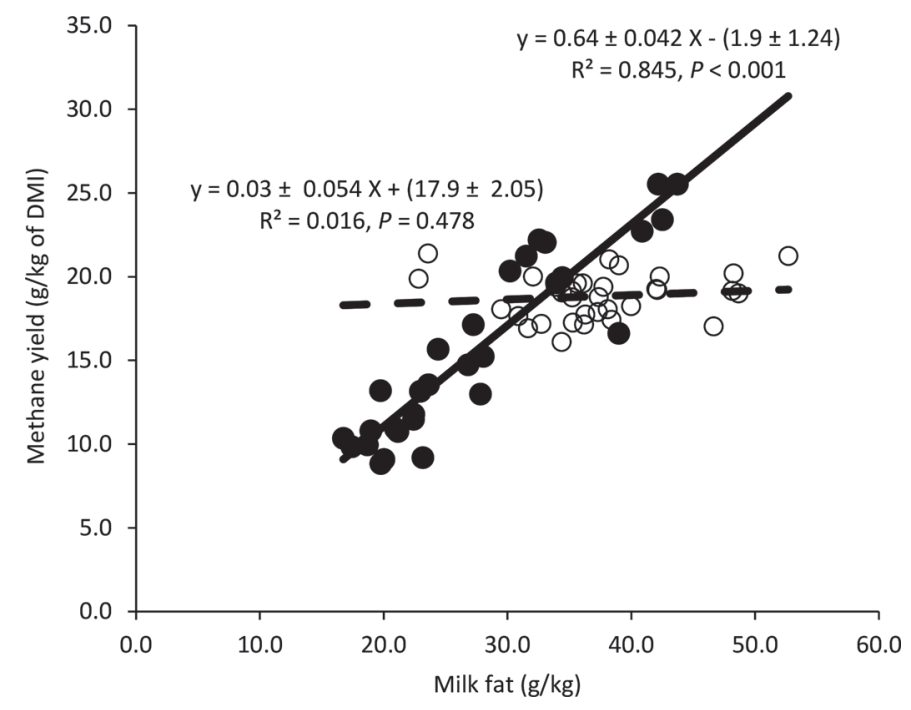

Figure 2. Relationships between milk fat concentration and $\mathrm{CH}_{4}$ yield for cows fed the corn $(\mathrm{O})$ and wheat $(\bullet)$ diets. 
Table 5. Influence of diet on $\mathrm{pH}$, and concentrations of constituents, of ruminal fluid sampled $4 \mathrm{~h}$ after the start of feeding at wk 4 , 10 , and 16 of the experiment ${ }^{1}$

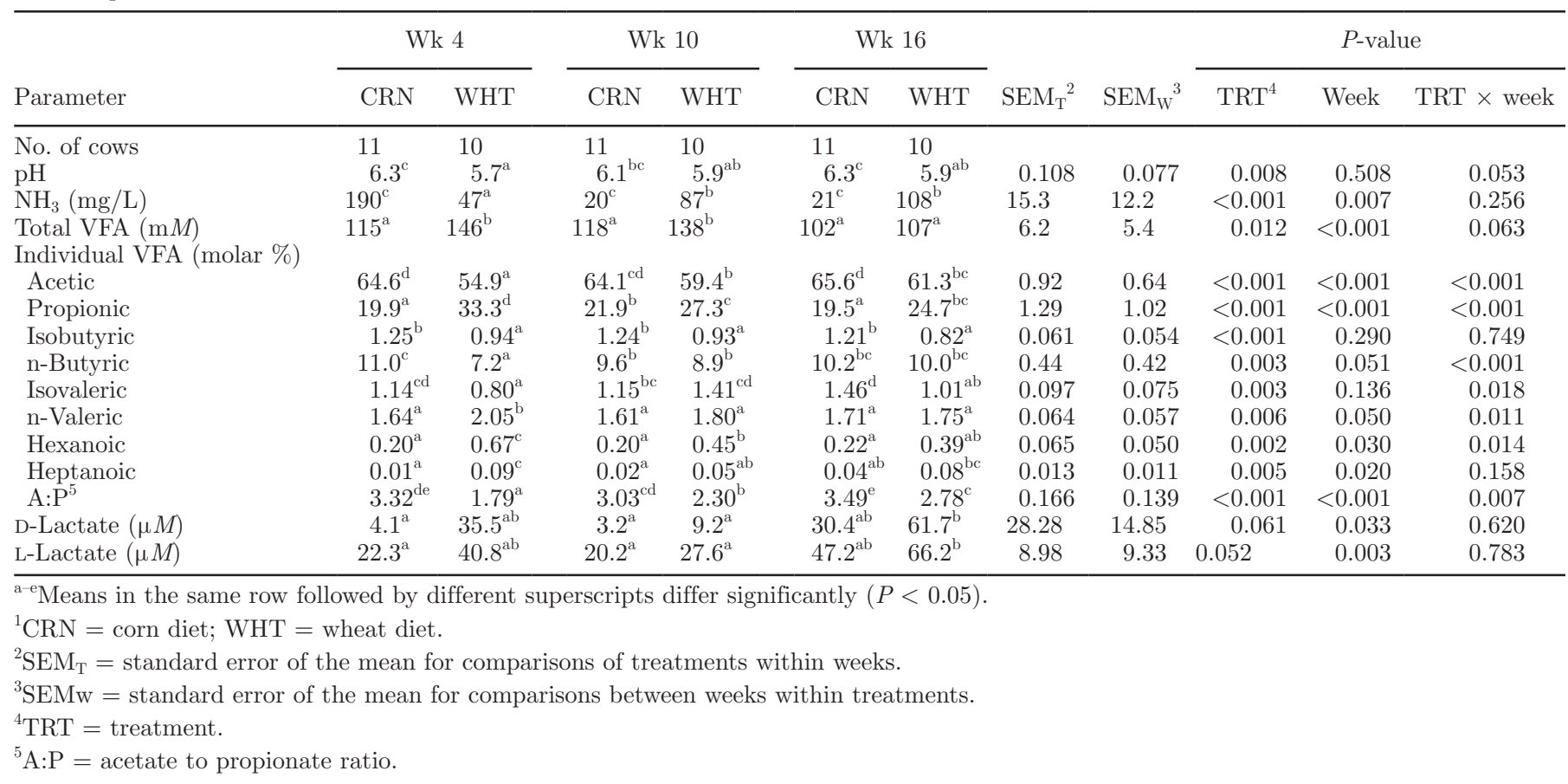

\section{Individual Cow Responses}

In cows fed the WHT diet, the adaptation response over time in milk fat concentration was not consistent in all cows (Figure 4A). Of the 10 cows fed the WHT diet, 4 cows (cows $\mathrm{A}, \mathrm{B}, \mathrm{C}$, and $\mathrm{D}$ ) were considered poorly adapted to the WHT diet. These 4 cows had a milk fat concentration (mean $\pm \mathrm{SD}$ ) of $18.8 \pm 1.49 \mathrm{~g} /$ $\mathrm{kg}$ at wk 4 , and by wk 16 their milk fat concentration was only $20.6 \pm 1.71 \mathrm{~g} / \mathrm{kg}$. In contrast, we considered 5 cows (E, F, G, H, and I) to have adapted well to the WHT diet. At wk 4, these cows had a milk fat concentration of $21.5 \pm 2.50 \mathrm{~g} / \mathrm{kg}$, but by wk 16 their milk fat concentration had increased to $37.2 \pm 4.73 \mathrm{~g} / \mathrm{kg}$. Of the cows fed the WHT diet, cow J had the highest milk fat concentration at wk 4 and 10, and the third highest milk fat concentration at wk 16 .

In terms of individual cow responses in milk fat yields over time, the 4 cows (A, B, C, and D) that responded poorly in milk fat concentration also had the lowest milk fat yields $(0.75 \pm 0.157 \mathrm{~kg} / \mathrm{d})$ at wk 16 , whereas cows $\mathrm{E}, \mathrm{F}, \mathrm{G}, \mathrm{H}$, and $\mathrm{I}$ that adapted well in terms of milk fat concentration also had high milk fat yields $(1.22 \pm 0.115 \mathrm{~kg} / \mathrm{d})$ at wk 16 (Figure 4B).

The 4 cows that adapted poorly to the WHT diet in terms of their milk fat concentration (i.e., cows A, B, $\mathrm{C}$, and D) had mean $\mathrm{CH}_{4}$ yields of $9.6 \pm 0.71$ at wk 4 and $12.0 \pm 1.34 \mathrm{~g} / \mathrm{kg}$ of DMI at wk 16 (Figure 4C). In contrast, the 5 cows that adapted well with respect to their milk fat concentrations (i.e., cows E, F, G, H, and I) had $\mathrm{CH}_{4}$ yields of $11.0 \pm 1.69 \mathrm{~g} / \mathrm{kg}$ of DMI at wk 4 and $22.1 \pm 2.47 \mathrm{~g} / \mathrm{kg}$ of DMI at wk 16 (Figure $4 \mathrm{C}$ ). Thus, cows that adapted well in terms of their milk fat response also adapted well in terms of their $\mathrm{CH}_{4}$ response.

The concentrations of trans-10 C18:1 versus week for individual cows in the WHT treatment group are shown in Figure 4E, whereas similar data on trans10,cis-12 C18:2 are shown in Figure 4F. The 4 cows that adapted poorly to the WHT diet in terms of their milk fat concentration (i.e., cows A, B, C, and D) had mean concentrations of trans-10 C18:1 of $7.4 \pm 1.43$ at wk $4,2.3 \pm 0.61$ at wk 10 , and $4.2 \pm 2.08 \mathrm{~g} / 100 \mathrm{~g}$ of total fatty acids at wk 16 . In contrast, the 5 cows that adapted well with respect to their milk fat concentrations (i.e., cows E, F, G, H, and I) had mean concentrations of trans-10 C18:1 of $6.6 \pm 3.38$ at wk $4,1.9 \pm 1.11$ at wk 10 , and $1.2 \pm 0.33 \mathrm{~g} / 100 \mathrm{~g}$ of total fatty acids at wk 16 . Similarly, the 4 cows that adapted poorly to the WHT diet in terms of their milk fat concentration had mean concentrations of trans-10,cis-12 C18:2 of $0.09 \pm$ 0.017 at wk $4,0.06 \pm 0.013$ at wk 10 , and $0.09 \pm 0.035$ $\mathrm{g} / 100 \mathrm{~g}$ of total fatty acids at wk 16 . In contrast, the 5 cows that adapted well with respect to their milk fat concentrations (i.e., cows E, F, G, H, and I) had mean concentrations of trans-10,cis-12 C18:2 of $0.10 \pm 0.029$ at wk $4,0.06 \pm 0.030$ at wk 10 , and $0.04 \pm 0.008 \mathrm{~g} / 100$ $\mathrm{g}$ of total fatty acids at wk 16 . Thus, over the 16 -wk 


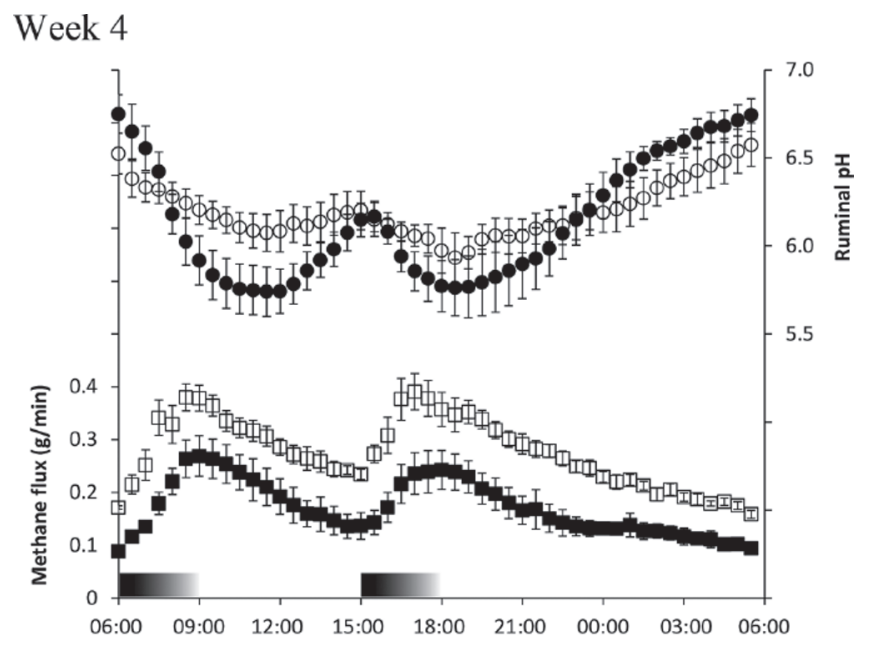

Week 10

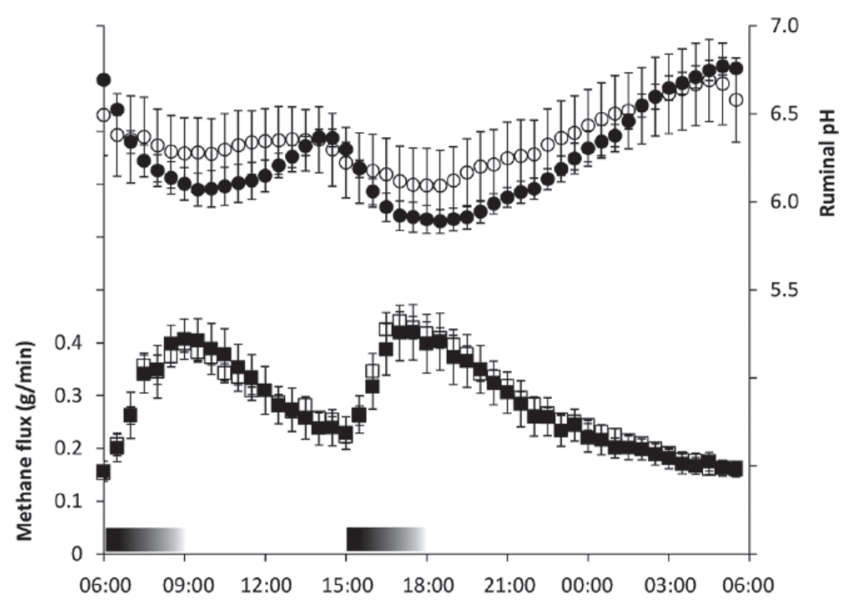

Week 16

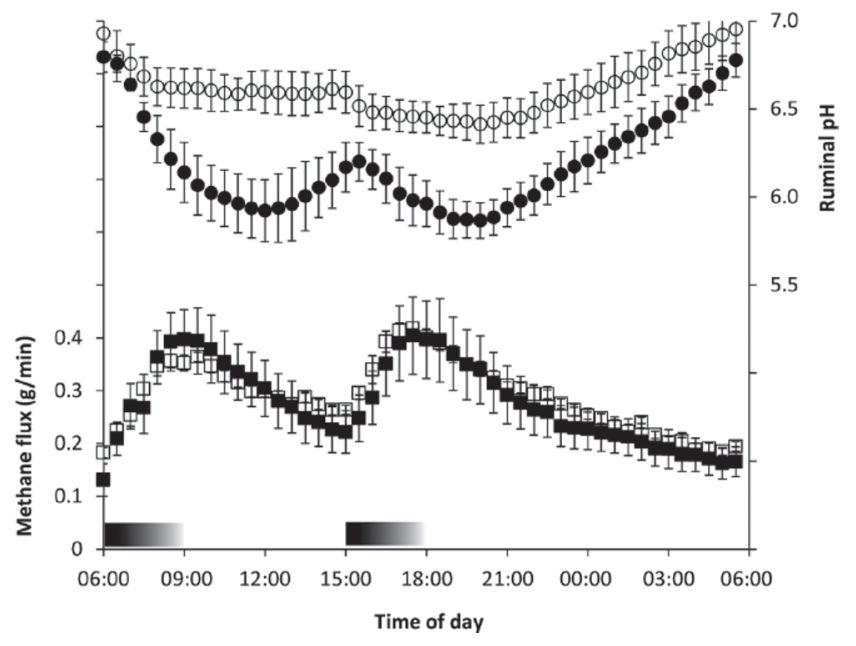

Figure 3. Twenty-four hour profiles of rumen fluid $\mathrm{pH}$ (upper graphs) and simultaneous $\mathrm{CH}_{4}$ fluxes (lower graphs) for the same cows fed the corn diet (hollow symbols) and the wheat diet (solid symbols) at wk 4, 10, and 16. Each datum depicted is the mean of measurements on 6 cows with associated SEM. The shaded bars represent the 2 periods of active eating that occurred after the morning and afternoon milkings. experiment, the poor adapters maintained numerically greater concentrations of trans-10 $\mathrm{C} 18: 1$ and trans10, cis-12 C18:2 than the good adapters.

In cows fed the WHT diet, the adaptation response over time, in terms of the A:P ratio, was not consistent in all cows (see Figure 4D). The 4 cows that poorly adapted to the WHT diet in terms of their milk fat concentration (i.e., cows A, B, C, and D) had mean A:P ratios of $1.38 \pm 0.069$ at wk 4 and $1.76 \pm 0.298$ at wk 16 (Figure 4D). In contrast, the 5 cows that adapted well with respect to their milk fat concentrations (i.e., cows E, F, G, H, and I), had A:P ratios of $1.71 \pm$ 0.369 at wk 4 and $3.28 \pm 0.721$ at wk 16 (Figure 4D). Thus, cows that adapted well in terms of their milk fat response and their $\mathrm{CH}_{4}$ response also adapted well in terms of their $\mathrm{A}: \mathrm{P}$ ratio.

\section{DISCUSSION}

Few reports are available in the scientific literature on the comparative responses in milk yield, milk composition, and $\mathrm{CH}_{4}$ emissions when dairy cows are fed similar diets containing either corn grain or wheat grain (Moate et al., 2017). Furthermore, the majority of previous experiments that examined the effects of wheat feeding on milk yield and composition were less than 4 wk duration, which ignores the possibility for adaptation over time (Gozho and Mutsvangwa, 2008; Leddin et al., 2010; Guo et al., 2013). This is the first report to compare over an extended period the effects of feeding wheat-based diets with corn-based diets for effects on milk yield, milk fat yield, milk composition, and $\mathrm{CH}_{4}$ emissions.

At wk 4, cows fed the CRN diet produced milk with higher milk fat concentration and milk fat yield, and emitted more $\mathrm{CH}_{4}$ and had a greater $\mathrm{CH}_{4}$ yield than cows fed the WHT diet. Thus, we accept our first hypothesis. At wk 4, the cows fed the WHT diet exhibited the symptoms of milk fat depression as their milk fat concentration was very low $(22.9 \mathrm{~g} / \mathrm{kg})$, and their protein concentration $(31.6 \mathrm{~g} / \mathrm{kg})$ and lactose concentration $(52.0 \mathrm{~g} / \mathrm{kg}$ ) were in the normal range (Harvatine et al., 2009). This milk fat depressing effect of the WHT diet was still evident at wk 10, but at wk 16, the milk fat concentrations of the cows fed the WHT and CRN diets were not different. This finding is contrary to our second hypothesis that milk fat concentrations and fatty acid profiles would not change over the course of the experiment. In previous short-term experiments, the effects of wheat feeding on milk fat concentration have been equivocal with some studies reporting wheat reduced milk fat concentration (Gozho and Mutsvangwa, 2008; Guo et al., 2013; Moate et al., 2017) and others reporting little or no effect (Tommervik and 
Table 6. Influence of diet on $\mathrm{pH}$ parameters ${ }^{1}$ in the ruminal fluid of rumen fistulated cows during wk 4,10 , and 16 of the experiment $^{2}$

\begin{tabular}{|c|c|c|c|c|c|c|c|c|c|c|c|}
\hline Parameter & \multicolumn{2}{|c|}{ Wk 4} & \multicolumn{2}{|c|}{ Wk 10} & \multicolumn{2}{|c|}{ Wk 16} & $\mathrm{SEM}_{\mathrm{T}}^{3}$ & $\mathrm{SEM}_{\mathrm{W}}{ }^{4}$ & \multicolumn{3}{|c|}{$P$-value } \\
\hline No. of cows & 5 & 5 & 5 & 5 & 5 & 5 & & & & & \\
\hline Minimum $\mathrm{pH}$ & $5.72^{\mathrm{a}}$ & $5.65^{\mathrm{a}}$ & $6.03^{\mathrm{b}}$ & $5.80^{\mathrm{ab}}$ & $6.15^{\mathrm{b}}$ & $5.81^{\mathrm{ab}}$ & 0.126 & 0.094 & 0.007 & 0.017 & 0.366 \\
\hline Maximum $\mathrm{pH}$ & $6.81^{\mathrm{a}}$ & $7.09^{\mathrm{ab}}$ & $6.91^{\mathrm{ab}}$ & $6.95^{\mathrm{ab}}$ & $6.99^{\mathrm{ab}}$ & $7.22^{\mathrm{b}}$ & 0.130 & 0.126 & 0.240 & 0.342 & 0.615 \\
\hline Duration below $\mathrm{pH} 6(\mathrm{~min} / \mathrm{d})$ & 313 & 472 & 86 & 255 & 98 & 361 & 130.8 & 106.5 & 0.147 & 0.131 & 0.865 \\
\hline
\end{tabular}

\footnotetext{
${ }^{\mathrm{a}, \mathrm{b}}$ Means in the same row followed by different superscripts differ significantly $(P<0.05)$.

${ }^{1}$ Measured by means of intraruminal boli.

${ }^{2} \mathrm{CRN}=$ corn diet; WHT $=$ wheat diet.

${ }^{3} \mathrm{SEM}_{\mathrm{T}}=$ standard error of the mean for comparisons of treatments within weeks.

${ }^{4} \mathrm{SEM}_{\mathrm{w}}=$ standard error of the mean for comparisons between weeks within treatments.

${ }^{5} \mathrm{TRT}=$ treatment
}

Waldern, 1969; Waldern and Cedeno, 1969; O'Mara et al., 1997; Leddin et al., 2010), or even an increase in milk fat concentration (Faldet et al., 1989). In the current experiment, the substantially lower milk fat concentration and milk fat yield at wk 4 in cows fed the WHT diet compared with these metrics in cows fed the CRN diet are consistent with findings from a previous short-term experiment in which cows were fed similar diets (Moate et al., 2017). However, as far as we can ascertain, the adaptation response (i.e., the increase in milk fat concentration over time and the recovery in milk fat yield) in cows fed a wheat-based diet has not previously been reported in the scientific literature, and may partly explain why there have been variable findings with respect to the effect of wheat feeding on milk fat concentration. Indeed, based on the findings of this experiment, findings from previous short-term published experiments using Latin square and crossover designs (e.g., Faldet et al., 1989; Guo et al., 2013) involving comparisons of wheat based diets with diets containing other cereal grains may be compromised by failure to allow for the development of long-term effects and by the possibility of carry-over effects.

\section{Milk Fatty Acids}

Many of our findings with respect to differences in concentrations of specific fatty acids in the milk of cows fed the CRN and WHT diets at wk 4 confirm our previous findings when cows were fed similar diets for a period of approximately $5 \mathrm{wk}$ (Moate et al., 2017). The finding that many of these differences were not present at wk 10 and 16 is novel and indicates that over weeks, cows adapt to being fed wheat by altering the fatty acid composition of milk. Moreover, over the course of the experiment, in cows fed the WHT diet, the concentrations of many individual fatty acids changed. For example, in the milk fat of cows fed the WHT diet, the concentrations of trans-10,cis-12 C18:2 were 976, 597 , and $594 \mathrm{mg} / \mathrm{kg}$ of total fatty acids at wk 4,10 , and 16, respectively. These findings are also contrary to our second hypothesis. In the current experiment, the negative correlation between the milk concentration of trans-10,cis-12 C18:2 and the total milk fat concentration can be explained by the fact that trans-10, cis-12 C18:2 is known to act in the mammary gland as an inhibitor of milk fat production (Bauman and Griinari, 2003). The current research also confirms previous reports of negative associations between milk concentrations of trans-10 C18:1 and milk fat concentration (Griinari et al., 1998; Kadegowda et al., 2008; Moate et al., 2017). The fact that over the 16 wk of this experiment, total milk fat concentrations were negatively associated with concentrations of both trans-10, cis-12 C18:2 and trans-10 C18:1 suggests that the adaptation process was not due to a build-up of tolerance within the mammary gland to the inhibitory effects of these 2 fatty acids. Both trans-10,cis-12 C18:2 and trans-10 $\mathrm{C} 18: 1$ are formed in the rumen and transported to the mammary gland where they are incorporated into triglycerides which constitute the majority of milk fat. The data in Tables 2 and 3, as well as Figures $4 \mathrm{E}$ and $4 \mathrm{~F}$, indicate that over the $16 \mathrm{wk}$ of this experiment a general decline occurred in the milk concentrations of both trans-10 C18:1 and trans-10,cis-12 C18:2, suggesting that the adaptation in milk fat concentration was due to a decline in the amounts of these fatty acids formed in the rumen. Low $\mathrm{pH}$ in ruminal fluid has been shown to inhibit ruminal biohydrogenation and isomerization of long-chain UFA (Troegeler-Meynadier et al., 2003), and inhibition of ruminal biohydrogenation can lead to an increase in the formation of both trans-10 C18:1 and trans-10,cis-12 C18:2. However, it is unlikely that the change in the production of both trans-10 C18:1 and trans-10,cis-12 C18:2 were related to $\mathrm{pH}$ as the data in Tables 5 and 6 and in Figure 3 

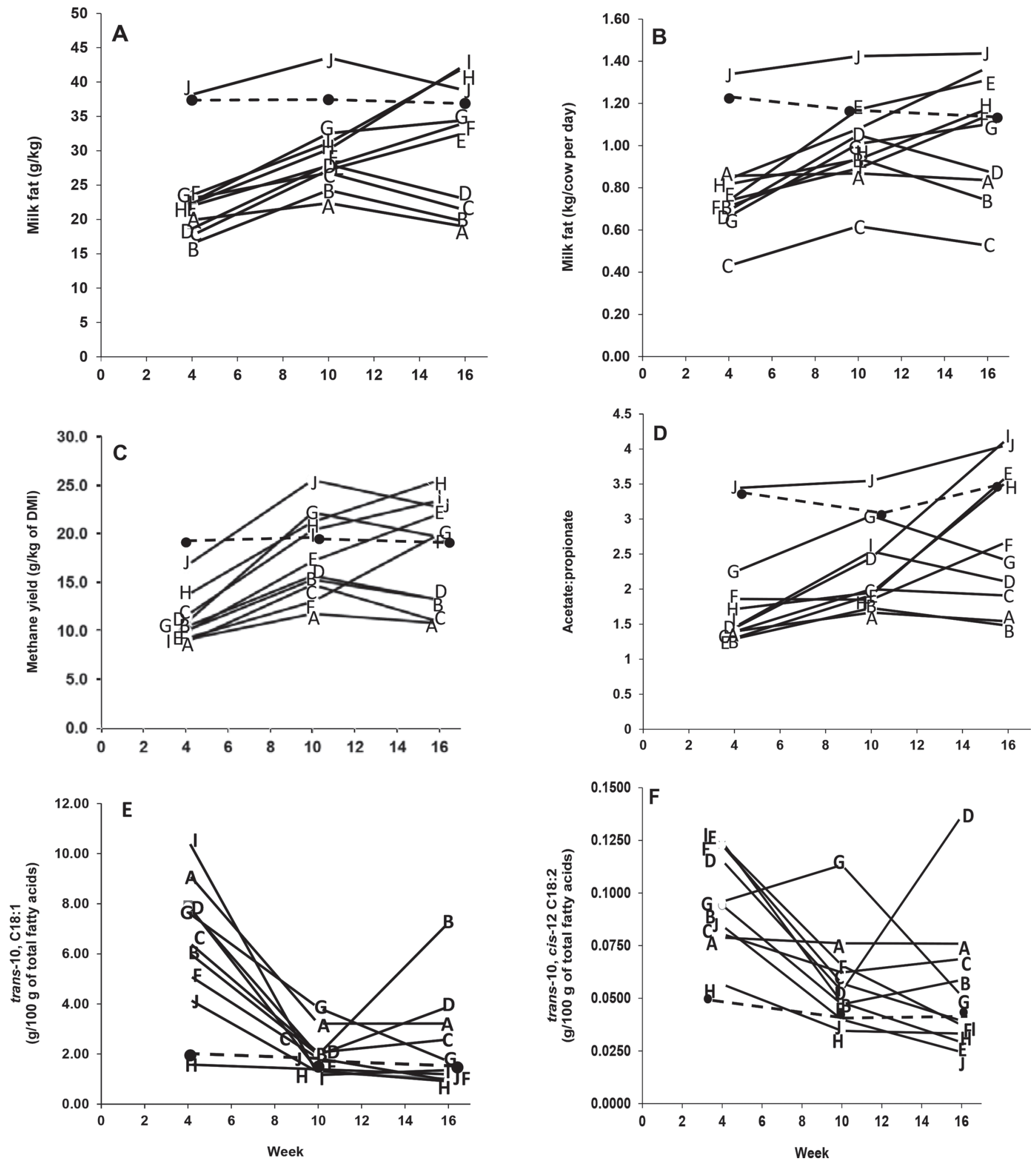

Figure 4. Responses in milk fat concentration (A), milk fat yield (B), $\mathrm{CH}_{4}$ yield (C), acetate-to-propionate ratio (D), trans-10 C18:1 (E), and trans-10,cis-12 C18:2 (F) at wk 4, 10, and 16. Data from individual cows fed the wheat dietary treatment are depicted by letters A to J. The solid lines joining data are included to facilitate the depiction of the time course trajectories of individual cow responses over the experimental period. The $(\bullet$ ) markers depict the means for cows fed the corn treatment. 
indicate no substantial changes in $\mathrm{pH}, \mathrm{pH}$ parameters, or $\mathrm{pH}$ patterns.

Cows A, B, C, and D maintained low milk fat concentrations over the entire 16 wk of the experiment, with their individual data points for milk fat concentration tightly clustered at wk 4, 10, and 16 . In this experiment, the data for milk fat concentrations of trans-10 C18:1 and trans-10,cis-12 C18:2 did not cluster in a similar fashion to the data for total milk fat concentration. This observation suggests that factors other than trans-10 C18:1 and trans-10,cis-12 C18:2 may influence milk fat concentration.

\section{Methane}

Methane emissions, $\mathrm{CH}_{4}$ yield, and $\mathrm{CH}_{4}$ intensity were all substantially decreased at wk 4 in the cows fed the WHT diet compared with the CRN diet, but contrary to our third hypothesis, no differences were observed in these metrics at wk 10 or 16 . This decline in $\mathrm{CH}_{4}$ suppression is similar to the adaptation responses in milk fat concentration and milk fat yield. Our findings at wk 4 , with respect to decreased $\mathrm{CH}_{4}$ emissions, $\mathrm{CH}_{4}$ yield, and $\mathrm{CH}_{4}$ intensity in cows fed the WHT diet in comparison to cows fed the CRN diet are similar to previous findings, and we have previously discussed possible dietary reasons for the differences in these $\mathrm{CH}_{4}$ metrics (Moate et al., 2017). However, as far as we can ascertain, this is the first report to describe the transitory nature of the anti-methanogenic effect associated with the feeding of wheat in some but not all cows. Furthermore, this is the first report to link the milk fat concentration of cows fed a diet containing wheat to their $\mathrm{CH}_{4}$ yield (see Figure 2) and also the adaptation response over time, in milk fat concentration, to the diminishing $\mathrm{CH}_{4}$ inhibitory effect associated with the feeding of wheat.

\section{Ruminal $\mathrm{pH}$ and Fermentation}

The mean $\mathrm{pH}$ of ruminal fluid at $4 \mathrm{~h}$ after feeding (Table 5), was substantially greater in the cows fed the CRN diet compared with that in cows fed the WHT diet. Furthermore, there was no effect of week and no interaction of treatment $\times$ week on mean $\mathrm{pH}$ of ruminal fluid. In the current experiment, at wk 4, the substantially lower ruminal fluid $\mathrm{pH}$ in cows fed the WHT diet compared with the $\mathrm{pH}$ in cows fed the $\mathrm{CRN}$ diet is consistent with our findings from a previous short-term experiment in which cows were fed a similar diet for a similar duration (Moate et al., 2017).

Low $\mathrm{pH}$ in ruminal fluid has previously been associated with both low milk fat concentration and low enteric $\mathrm{CH}_{4}$ production (Moate et al., 2017). The mechanism by which low $\mathrm{pH}$ in ruminal fluid can lead to reduced $\mathrm{CH}_{4}$ production is not as clear. Moate et al. (2017) showed that it is the daily nadir in ruminal fluid $\mathrm{pH}$ that is most strongly related to the magnitude of the rate of $\mathrm{CH}_{4}$ production. In the present research, cows fed the CRN and WHT diets exhibited W-shaped circadian patterns of $\mathrm{pH}$ in ruminal fluid, and these patterns were similar to those previously reported for cows fed similar corn- and wheat-based diets in a shortterm experiment (Moate et al., 2017). At wk 4, 10, and 16, the cows fed the WHT diet exhibited lower nadirs in ruminal fluid $\mathrm{pH}$ than cows fed the CRN diet. Moreover, for the cows fed the WHT diet, despite the fact that the patterns of ruminal fluid $\mathrm{pH}$ were almost identical at wk 4 and 16, the milk fat percentages and the magnitudes of the rates of $\mathrm{CH}_{4}$ production were both quite different at these 2 periods. This finding indicates that there is not a simple relationship between ruminal fluid $\mathrm{pH}$ and these parameters and although at wk 4, nadir of $\mathrm{pH}$ was positively correlated with $\mathrm{CH}_{4}$ emissions and $\mathrm{CH}_{4}$ yield, this was not the case at wk 10 and 16. Thus, on the basis of these findings, we reject our fourth hypothesis that $\mathrm{CH}_{4}$ yield would be correlated with the daily nadir in $\mathrm{pH}$ of ruminal fluid.

\section{Adaptation}

The similarity in the patterns of ruminal fluid $\mathrm{pH}$ at wh 4, 10, and 16 suggests that the adaptation process with respect to $\mathrm{CH}_{4}$ production did not involve a marked change in the total rate of acid production. However, cows fed the WHT diet had lower $(P<0.001)$ acetate percentage, higher propionate percentage, and lower A:P ratio in ruminal fluid than cows fed the CRN diet. These findings support results from some previous short-term experiments involving the feeding of wheat and corn (Gozho and Mutsvangwa, 2008; Guo et al., 2013; Moate et al., 2017).

A novel finding of the current experiment is that in the longer term (i.e., over the $16 \mathrm{wk}$ of the experiment) for the cows fed the WHT diet, a linear increase occurred in the molar percentage of acetic acid and a decrease in molar percentage of propionic acid. The ruminal synthesis of acetic acid is accompanied by the production of hydrogen reducing equivalents (metabolic hydrogen), while the synthesis of propionic acid consumes metabolic hydrogen (Demeyer 1991). Metabolic hydrogen is a substrate that is used in the ruminal production of $\mathrm{CH}_{4}$ (Janssen 2010) and also used in the biohydrogenation of UFA (Demeyer, 1991; Jenkins et al., 2008). For cows fed the WHT diet, the A:P ratio increased from 1.79 at wk 4 to 2.3 at wk 10 and 2.78 at wk 16 . The A:P ratio has previously been shown to correlate with the magnitude of $\mathrm{CH}_{4}$ emissions (Mohammed et al., 2004). 
Thus, it is not surprising that for cows fed the WHT diet, the increases $(P<0.05)$ in A:P ratio at wk 10 and 16 , compared with wk 4 , were associated with increases in $\mathrm{CH}_{4}$ emissions, yield, and intensity. The interactions between dietary treatment and week for the molar percentage concentrations of acetic, propionic, n-butyric, iso-valeric, n-valeric, and hexaenoic acids, as well as for the A:P ratio, are all evidence of substantial adaptation changes in ruminal fermentation processes during the $16 \mathrm{wk}$ of the experiment. These changes in ruminal fermentation necessarily must involve changes in either populations of ruminal microorganisms or changes in the activities of microorganisms. Furthermore, evidence for substantial changes in ruminal fermentation over the $16 \mathrm{wk}$ of the experiment is provided by the changes in the concentrations of various fatty acids in milk. In the rumen, metabolic hydrogen is used to biohydrogenate unsaturated long-chain fatty acids (Jenkins et al., 2008). Therefore, the marked increase in concentrations of total SFA and decrease in concentrations of total MUFA and total PUFA at wk 10 and 16, in comparison to the corresponding concentrations at wk 4 , is evidence of either an increase in the ruminal production of metabolic hydrogen over the course of the experiment or an increase in the populations of ruminal bacteria that produce biohydrogenation enzymes and or the activity of those enzymes. It has also been reported that a strong relationship is present between the concentration of C17:0 in milk and rumen function (Fievez et al., 2012). In particular, a relationship is present between the C17:0 yield in milk and the microbial protein flow from the rumen (Fievez et al., 2012). For cows fed the WHT diet, the yields C17:0 in milk at wk 4, 10, and 16 can be calculated as $14.3,11.3$, and $11.4 \mathrm{mg} / \mathrm{d}$, respectively. This suggests a substantial change in the total daily microbial production in the rumen between wk 4 , 10 , and 16 .

The finding that cows that did not adapt well in their milk fat concentration also did not adapt well in their $\mathrm{CH}_{4}$ yields and $\mathrm{A}: \mathrm{P}$ ratio, whereas cows that did adapt well in their milk fat concentration also adapted well in their $\mathrm{CH}_{4}$ yields and A:P ratios suggest that the adaptation process affects these 3 parameters. The finding that the adaptation process took place over 16 wk is surprising. Many experiments are short-term (i.e., less than 5 wk duration) because of the widespread belief that the majority of ruminal adaptation takes place within about 2 wk (Kaufmann et al., 1980). However, there is evidence that under some circumstances, ruminal adaptations may take many weeks (Weimer et al., 2010).

Stearoyl-CoA desaturase 1 is an enzyme that occurs in both the liver and mammary gland, and its func- tion is to introduce a cis-9 bond into saturated longchain fatty acids (Rincon et al., 2012). The C14D9R, C16D9R, and C18D9R indexes are proxies for the activity of the stearoyl-CoA desaturase enzyme, and the fact that for the cows offered the WHT diet, these indexes declined after wk 4, provides evidence that some of the adaptation process may have taken place within the liver or mammary gland. The fact that in the current experiment, treatment differences in terms of milk fat concentration and $\mathrm{CH}_{4}$ emissions were quite different at wk 4 compared with wk 16, and our observation that adaptation changes in ruminal fermentation parameters were still occurring at wk 16, highlight the disadvantage of short-term (i.e., less than $4 \mathrm{wk}$ ) experiments to quantify important dietary effects on production and $\mathrm{CH}_{4}$ emissions. Further research will be required to elucidate how the archaeal and microbial populations adapt over time to a diet containing a high proportion of wheat.

The mechanisms and causes for the adaptation responses over time in milk fat concentration and $\mathrm{CH}_{4}$ emissions are not clear. In this experiment, over the 16 wk of the experiment, the chemical composition of the feeds and the daily quantities of the feeds offered to the cows did not change, and over the 16 wk of the experiment, there were only minor variations in the daily amounts of both diets consumed and the percentage of grain in the diets. The suggestion that adaptation in milk fat concentration over time was due to a decline in the amounts of certain fatty acids formed in the rumen implies that the rumen microbiome changed over the course of the experiment. Indeed, Pitta et al. (2018) showed that alterations occur in ruminal bacterial populations at induction and recovery from diet-induced milk fat depression in dairy cows. What remains to be elucidated is why some cows are adaptive in that they spontaneously recover from milk fat depression whereas other cows continue to exhibit milk fat depression for an extended period.

\section{Implications of This Research}

(1) Findings from short-term experiments may not accurately reveal the long-term effects of specific diets.

(2) Attempts to predict either milk fat concentrations or $\mathrm{CH}_{4}$ yields of dairy cows using simple mathematical models based mainly on DMI and dietary nutrient concentrations may not be very accurate unless they take adaptation into account. There are, therefore, still formidable challenges to be overcome before either empirical or dynamic/mechanistic models will be able 
to accurately predict milk fat concentration and $\mathrm{CH}_{4}$ yields of dairy cows.

(3) If, as is suggested by this research, there exists a cohort of cows that are poorly adaptive and a cohort that adapts well to dietary changes, then future research will be required to elucidate the underlying mechanisms for these phenotypes, the attributes of these phenotypes, and the possibility that cow genetics may be involved. Adaptive phenotypes may be desirable for production purposes, but nonadaptive phenotypes may be desirable for $\mathrm{CH}_{4}$ mitigation.

\section{CONCLUSIONS}

This experiment confirmed that in the short term (i.e., up to $4 \mathrm{wk}$ ) the feeding of wheat to dairy cows is associated with decreased milk fat concentration, decreased milk fat yield, and decreased emission, yield, and intensity of $\mathrm{CH}_{4}$ in lactating dairy cows. However, the important novel finding of this research was that these effects were transitory, in that the decreased milk fat yield, decreased $\mathrm{CH}_{4}$ yield, and decreased $\mathrm{CH}_{4}$ emissions that occurred in the short term were not present by wk 10. Over 16 wk of this experiment, some cows did not adapt well to the wheat feeding but other cows adapted by increasing their $\mathrm{A}: \mathrm{P}$ ratio in ruminal fluid, increasing their $\mathrm{CH}_{4}$ yields, milk fat concentrations and milk fat yields. The mechanisms involved in these adaptation effects are not clear, but do not involve a change in the circadian patterns of $\mathrm{pH}$ in ruminal fluid. We propose that differences in the ability of individual cows to adapt to diets containing a high proportion of wheat may have substantial ramifications for dairy industries in several countries, and further research in this field is warranted. The scientific literature contains numerous articles describing short-term experiments concerned with dietary interventions to mitigate enteric $\mathrm{CH}_{4}$ emissions from ruminants. This research shows that the results from short-term studies may not always be used to reliably predict the long-term effects of such interventions.

\section{ACKNOWLEDGMENTS}

This investigation was funded by the Victorian Department of Economic Development, Jobs, Transport and Resources; Emissions Reductions Alberta, Canada; and Dairy Australia. This work would not have been possible without the excellent work of the technical staff at Department of Economic Development, Jobs, Transport and Resources, Victoria, Ellinbank Centre (Australia).

\section{REFERENCES}

Bauman, D. E., and J. M. Griinari. 2003. Nutritional regulation of milk fat synthesis. Annu. Rev. Nutr. 23:203-227.

Beauchemin, K. A., and S. M. McGinn. 2005. Methane emissions from feedlot cattle fed barley or corn diets. J. Anim. Sci. 83:653-661.

Bligh, E. G., and W. J. Dyer. 1959. A rapid method of total lipid extraction and purification. Can. J. Biochem. Physiol. 37:911-917.

Dairy One. 2015. Analytical Procedures. Accessed Feb. 26, 2018. http://dairyone.com/wp-content/uploads/2014/02/Forage-Lab -Analytical-Procedures-Listing-Alphabetical-July-2015.pdf.

Demeyer, D. I. 1991. Quantitative aspects of microbiological metabolism in the rumen and hindgut. Pages 217-237 in Rumen Microbial Metabolism and Ruminant Digestion. J. P. Jouany, ed. INRA Editions, Paris, France.

Faldet, M. A., T. Nalsen, L. J. Bush, and G. D. Adams. 1989. Utilization of wheat in complete rations for lactating cows. J. Dairy Sci. 72:1243-1251.

Fievez, V., E. Colman, J. M. Castro-Montoya, I. Stefanov, and B. Vlaeminck. 2012. Milk odd- and branched-chain fatty acids as biomarkers of rumen function-An update. Anim. Feed Sci. Technol. 172:51-65.

Garner, J. B., M. L. Douglas, S. R. O. Williams, W. J. Wales, L. C. Marett, T. T. T. Nguyen, C. M. Reich, and B. J. Hayes. 2016. Genomic selection improves heat tolerance in dairy cows. Sci. Rep. 6:34114. https://doi.org/10.1038/srep34114.

Gawehn, K. 1988. D-(-)-Lactate. Pages 588-592 in Methods of Enzymatic Analysis 3rd ed., Vol VI. H. U. Bergmeyer, ed. VCH Publishers Ltd., Cambridge, UK.

Gozho, G. N., and T. Mutsvangwa. 2008. Influence of carbohydrate source on ruminal fermentation characteristics, performance, and microbial protein synthesis in dairy cows. J. Dairy Sci. 91:27262735. https://doi.org/10.3168/jds.2007-0809.

Grainger, C., and K. A. Beauchemin. 2011. Can enteric methane emissions from ruminants be lowered without lowering their production? Anim. Feed Sci. Technol. 166-167:308-320. https://doi.org/ 10.1016/j.anifeedsci.2011.04.021.

Grainger, C., T. Clarke, M. J. Auldist, K. A. Beauchemin, S. M. McGinn, G. C. Waghorn, and R. J. Eckard. 2009. Potential use of Acacia mearnsii condensed tannins to reduce methane emissions and nitrogen excretion from grazing dairy cows. Can. J. Anim. Sci. 89:241-251.

Griinari, J. M., D. A. Dwyer, M. A. McGuire, D. E. Bauman, D. L. Palmquist, and K. V. V. Nurmela. 1998. Trans-octadecenoic acids and milk fat depression in lactating cows. J. Dairy Sci. 81:12511261.

Guan, H., K. M. Wittenberg, K. H. Ominski, and D. O. Krause. 2006. Efficacy of ionophores in cattle for mitigation of enteric methane. J. Anim. Sci. 84:1896-1906.

Guo, Y. Q., Y. Zou, Z. J. Cao, X. F. Xu, Z. S. Yang, and S. L. Li. 2013. Evaluation of coarsely ground wheat as a replacement for ground corn in the diets of lactating dairy cows. Asian-Australas. J. Anim. Sci. 26:961-970.

Harvatine, K. J., J. W. Perfield, and D. E. Baumaan. 2009. Expression of enzymes and key regulators of lipid synthesis is upgraded in adipose tissue during CLA induced milk fat depression in dairy cows. J. Nutr. 139:849-854.

Hristov, A. N., J. Oh, F. Giallongo, T. W. Frederick, M. T. Harper, H. L. Weeks, A. F. Branco, P. J. Moate, M. H. Deighton, S. R. Williams, M. Kindermann, and S. Duval. 2015. An inhibitor persistently decreased enteric methane emission from dairy cows with no negative effect on milk production. Proc. Natl. Acad. Sci. USA 112:10663-10668.

Janssen, P. H. 2010. Influence of hydrogen on rumen methane formation and fermentation balances through microbial growth kinetics and fermentation thermodynamics. Anim. Feed Sci. Technol. 160:1-22

Jenkins, T. C., R. J. Wallace, P. J. Moate, and E. E. Mosley. 2008. Board-Invited Review: Recent advances in biohydrogenation of unsaturated fatty acids within the rumen microbial ecosystem. J. Anim. Sci. 86:397-412. 
Kadegowda, A. K. G., L. S. Piperova, and R. A. Erdman. 2008. Principal component and multivariate analysis of milk long-chain fatty acid composition during diet-induced milk fat depression. J. Dairy Sci. 91:749-759.

Kaufmann, W., H. Hagemeister, and G. Dirksen. 1980. Chapter 28: Adaptation to changes in dietary composition, level and frequency of feeding. Pages 587-602 in Digestive Physiology and Metabolism in Ruminants. Y. Ruckebusch and P. Thivend, ed. AVI Publishing Company Inc., Westport, CT.

Klop, G., J. Dijkstra, K. Dieho, W. H. Hendricks, and A. Bannink. 2017. Enteric methane production in lactating dairy cows with continuous feeding of essential oils or rotational feeding of essential oils and lauric acid. J. Dairy Sci. 100:3563-3575. https://doi.org/ 10.3168/jds.2016-12033.

Leddin, C. M., C. R. Stockdale, J. Hill, J. W. Heard, and P. T. Doyle. 2010. Increasing amounts of crushed wheat fed with Persian clover herbage reduced ruminal $\mathrm{pH}$ and dietary fibre digestibility in lactating dairy cows. Anim. Prod. Sci. 50:837-846.

Moate, P. J., M. H. Deighton, S. R. O. Williams, J. E. Pryce, B. J. Hayes, J. L. Jacobs, R. J. Eckard, M. C. Hannah, and W. J. Wales. 2016. Reducing the carbon footprint of Australian milk production by mitigation of enteric methane emissions. Anim. Prod. Sci. 56:1017-1034. https://doi.org/10.1071/AN15222.

Moate, P. J., S. R. O. Williams, M. H. Deighton, and W. J. Wales. 2012. A comparison between wheat or maize grain fed as a high proportion of the diet on milk production and methane emissions from dairy cows. Pages 452-453 in Proc. 5th Australasian Dairy Sci. Symp., Attwood, Victoria, Australia. Australasian Dairy Science Committee, Melbourne, Australia.

Moate, P. J., S. R. O. Williams, M. H. Deighton, W. J. Wales, and J. L. Jacobs. 2014a. Supplementary feeding of wheat to cows fed harvested pasture increases milk production and reduces methane yield. Pages 176-178 in Proc. 6th Australasian Dairy Sci. Symp. Hamilton, New Zealand. Australasian Dairy Science Committee, Hamilton, New Zealand.

Moate, P. J., S. R. O. Williams, C. Grainger, M. C. Hannah, E. N. Ponnampalam, and R. J. Eckard. 2011. Influence of cold-pressed canola, brewers grains and hominy meal as dietary supplements suitable for reducing enteric methane emissions from lactating dairy cows. Anim. Feed Sci. Technol. 166-167:254-264. https:// doi.org/10.1016/j.anifeedsci.2011.04.069.

Moate, P. J., S. R. O. Williams, J. L. Jacobs, M. C. Hannah, K. A. Beauchemin, R. J. Eckard, and W. J. Wales. 2017. Wheat is more potent than corn or barley for dietary mitigation of enteric methane emissions from dairy cows. J. Dairy Sci. 100:7139-7153. https://doi.org/10.3168/jds.2016-12482.

Moate, P. J., S. R. O. Williams, V. A. Torok, M. C. Hannah, B. E. Ribaux, M. H. Tavendale, R. J. Eckard, J. L. Jacobs, M. J. Auldist, and W. J. Wales. 2014b. Grape marc reduces methane emissions when fed to dairy cows. J. Dairy Sci. 97:5073-5087. https:// doi.org/10.3168/jds.2013-7588.

Mohammed, N., N. Ajisaka, Z. A. Lila, K. Hara, K. Mikuni, S. Kanda, and H. Itabashi. 2004. Effect of Japanese horseradish oil on methane production and ruminal fermentation in vitro and in steers. J. Anim. Sci. 82:1839-1846.

NHMRC. 2013. Australian code for the care and use of animals for scientific purposes. 8th ed. National Health and Medical Research Council, Canberra, Australia. Accessed Jan. 7, 2017. http://www .nhmrc.gov.au/publications/synopses/ea16syn.htm.

NRC. 2001. Nutrient Requirements of Dairy Cattle: Seventh Revised Edition. National Academies Press, Washington, DC. https://doi .org/10.17226/9825.

O'Mara, F. P., J. J. Murphy, and M. Rath. 1997. The effect of replacing dietary beet pulp with wheat treated sodium hydroxide, ground wheat, or ground corn in lactating cows. J. Dairy Sci. 80:530-540.
Omar, J. A. 2004. Effect of different ionophore treatments on some rumen metabolic measures of steers. Dirasat Agric. Sci. 31:178-184.

Packer, E. L., E. H. Clayton, and P. M. V. Cusack. 2011. Rumen fermentation and liveweight gain in beef cattle treated with monensin and grazing lush forage. Aust. J. Vet. Res. 89:338-345.

Pitta, D. W., N. Indugu, B. Vecchiarelli, D. E. Rico, and K. J. Harvatine. 2018. Alterations in ruminal bacterial populations at induction and recovery from diet-induced milk fat depression in dairy cows. J. Dairy Sci. 101:295-309. https://doi.org/10.3168/jds.2016 -12514 .

Rincon, G., A. Islas-Trejo, A. R. Castillo, D. E. Bauman, B. J. German, and J. F. Medrano. 2012. Polymorphisms in genes in the SREBP1 signalling pathway and SCD are associated with milk fatty acid composition in Holstein cattle. J. Dairy Res. 79:66-75.

Sauer, F. D., V. Fellner, R. Kinsman, J. K. G. Kramer, H. A. Jackson, A. J. Lee, and S. Chen. 1998. Methane output and lactation response in Holstein cattle with monensin or unsaturated fat added to the diet. J. Anim. Sci. 76:906-914.

Sauvant, D., S. Giger-Reverdin, A. Serment, and L. Broudiscou. 2011. Influences des régimes et de leur fermentation dans le rumen sur la production de méthane par les ruminants. INRA Prod. Anim. 24:433-446.

Taylor, A. G., and C. Savage. 2006. Fatty acid composition of New Zealand green-lipped mussels, Perna canaliculus: Implications for harvesting for n-3 extracts. Aquaculture 261:430-439.

Thornton, J. H., and F. N. Owens. 1981. Monensin supplementation and in vivo methane production by steers. J. Anim. Sci. 52:628 634.

Tommervik, R. S., and D. E. Waldern. 1969. Comparative feeding value of wheat, corn, barley, milo, oats, and a mixed concentrate ration for lactating cows. J. Dairy Sci. 52:68-73.

Torok, V. A., N. J. Percy, P. J. Moate, and K. Ophel-Keller. 2014. Influence of dietary docosahexaenoic acid supplementation on the overall rumen microbiota of dairy cows and linkages with production parameters. Can. J. Microbiol. 60:267-275.

Trei, J. E., R. C. Parish, Y. K. Singh, and G. C. Scott. 1971. Effect of methane inhibitors on rumen metabolism and feedlot performance of sheep. J. Dairy Sci. 54:536-540.

Troegeler-Meynadier, A., M. C. Nicot, C. Bayourthe, R. Moncoulon, and F. Enjalbert. 2003. Effects of pH and concentrations of linoleic and linolenic acids on extent and intermediates of ruminal biohydrogenation in vitro. J. Dairy Sci. 86:4054-4063.

Tyrrell, H. F., and J. T. Reid. 1965. Prediction of the energy value of cow's milk. J. Dairy Sci. 48:1215-1223.

van Zijderveld, S. M., W. J. J. Gerrits, J. Dijkstra, J. R. Newbold, R. B. A. Hulshof, and H. B. Perdok. 2011. Persistency of methane mitigation by dietary nitrate supplementation in dairy cows. J. Dairy Sci. 94:4028-4038. https://doi.org/10.3168/jds.2011-4236.

Waldern, D. E., and G. Cedeno. 1969. Comparative acceptability and nutritive value of barley, wheat mixed feed, and a concentrate ration in meal and pelleted forms for lactating cows. J. Dairy Sci. $53: 317-324$

Weimer, P. J., D. M. Stevenson, H. C. Mantovani, and S. L. C. Man. 2010. Host specificity of the ruminal bacterial community in the dairy cow following near total exchange of ruminal contents. J. Dairy Sci. 93:5902-5912. https://doi.org/10.3168/jds.2010-3500.

Williams, S. R. O., T. Clarke, M. C. Hannah, L. C. Marett, P. J. Moate, M. J. Auldist, and W. J. Wales. 2013. Energy partitioning in herbage-fed dairy cows offered supplementary grain during an extended lactation. J. Dairy Sci. 96:484-494. https://doi.org/10 $.3168 /$ jds.2012-5787.

Williams, S. R. O., P. J. Moate, M. C. Hannah, B. E. Ribaux, W. J. Wales, and R. J. Eckard. 2011. Background matters with the $\mathrm{SF}_{6}$ tracer method for estimating enteric methane emissions from dairy cows. Anim. Feed Sci. Technol. 170:265-276. https://doi.org/10 .1016/j.anifeedsci.2011.08.013. 